\title{
Facile Separation of Regioisomeric Compounds by a Heteronuclear Organometallic Capsule
}

Wen-Ying Zhang, Yue-Jian Lin, Ying-Feng Han,* and Guo-Xin Jin*

Department of Chemistry, Fudan University, 220 Handan Road, 200433 Shanghai, China

\section{Table of content}

Syntheis of complex 2, EXSY experiments

Structure of complex 2, Figure S1

NMR spectra, Figure S2-S31

X-ray diffraction studies details, Table S1-S2
Page 2

Page 3

Page 4-33

Page 34-37 
Synthesis of 2. AgOTf (28 mg, $0.11 \mathrm{mmol})$ was added to a solution of $\left[\mathrm{Cp}^{*}{ }_{2} \mathrm{Rh}_{2}(\mu-\mathrm{CA})\right] \mathrm{Cl}_{2}$ 1 (38 mg, $0.05 \mathrm{mmol})$ in $\mathrm{CH}_{3} \mathrm{OH} / \mathrm{H}_{2} \mathrm{O}(10 \mathrm{~mL}, 10: 1)$ at room temperature. The reaction mixture immediately turned to grass-green, and white solid $\mathrm{AgCl}$ precipitated from the solution over the course of $10 \mathrm{~min}$. The obtained suspension was filtered. The solvent was removed to give complex 2. Yield: $50 \mathrm{mg}, 98 \% .{ }^{1} \mathrm{H}$ NMR $\left(400 \mathrm{MHz}, \mathrm{CD}_{3} \mathrm{OD}, \mathrm{ppm}\right): \delta=$ $1.78\left(\mathrm{~s}, 30 \mathrm{H}, \mathrm{Cp}^{*}\right)$. Crystals of 2 were obtained by slowly vapour the methanol solution of 2.

\section{EXSY experiments}

The rates of encapsulation and dissociation of 4.0 equiv. of $p$-xylene or 2.0 equiv. of $p$-dibromobenzene in the presence of 1.0 equiv. of the capsule 4 were determined using the EXSY NMR spectroscopy.

Exchange spectroscopy (EXSY) experiments were recorded in $\mathrm{CD}_{3} \mathrm{OD}$ at $500 \mathrm{MHz}$ with use of a standard phase-sensitive NOESY pulse program (noesyph) with the following parameters: the acquisition was performed with 1024 (t2) $\times 256(\mathrm{t} 1)$ data points, in States-TPPI mode with $Z$ gradients selection, relaxation delay of $2 \mathrm{~s}$, and 4 scans per increment; sweep width of $4380 \mathrm{~Hz}$ in both dimensions at 298K. Processing was done after a Sine Square multiplication in F1 and F2 and Fourier transformation in $512 \times 512$ real points. Magnetization exchange rates were obtained from cross and diagonal peak integration using Sparky with mixing time of $300 \mathrm{~ms}$. EXSYCalc software was used to extract the magnetization exchange rate constants $k_{\text {in }}$ and $k_{\text {out }}$ from the integrations of bound and unbound capsule exchange diagonal- and cross-peaks. (Ref. Perrin, C. L.; Dwyer, T. J. Chem. Rev. 1990, 90, 935-967.) 


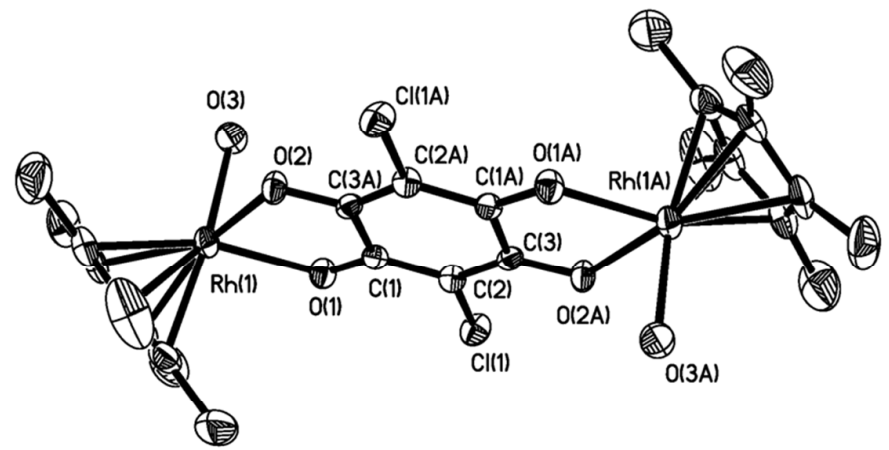

Figure S1. Thermal ellipsoids representation of crystal structure of 1. Hydrogen atoms and anions are omitted for clarity. 


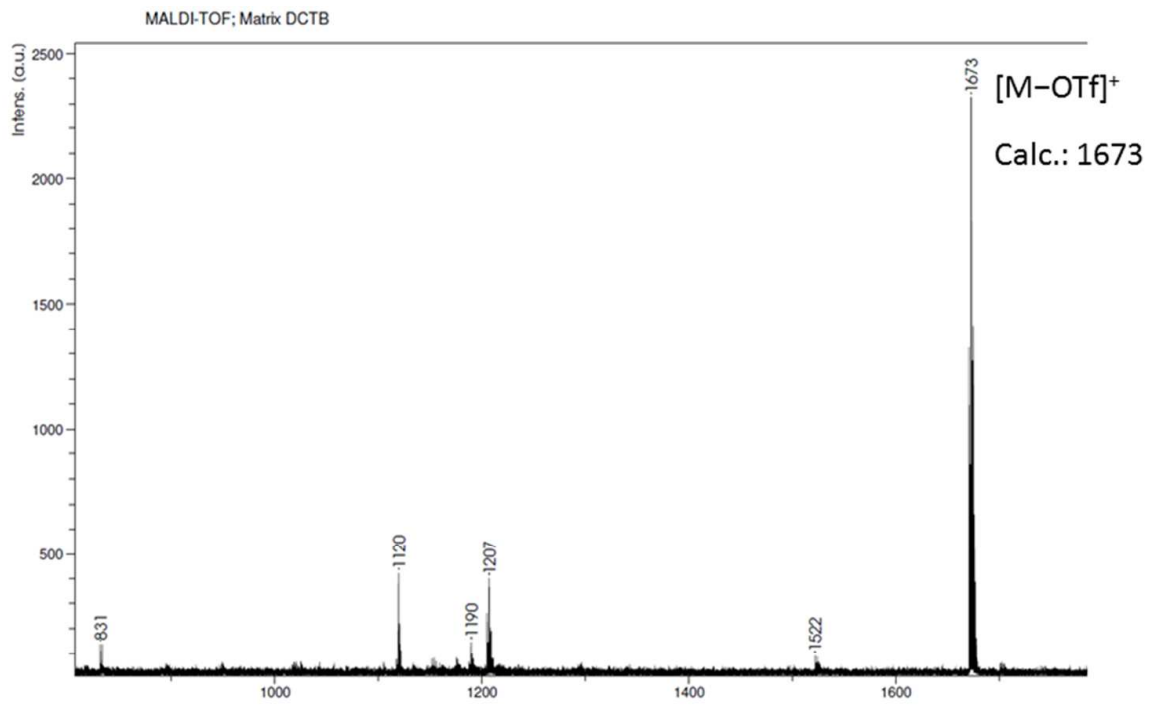

Figure S2. MALDI-TOF mass spectrum of complex 3. 
a)

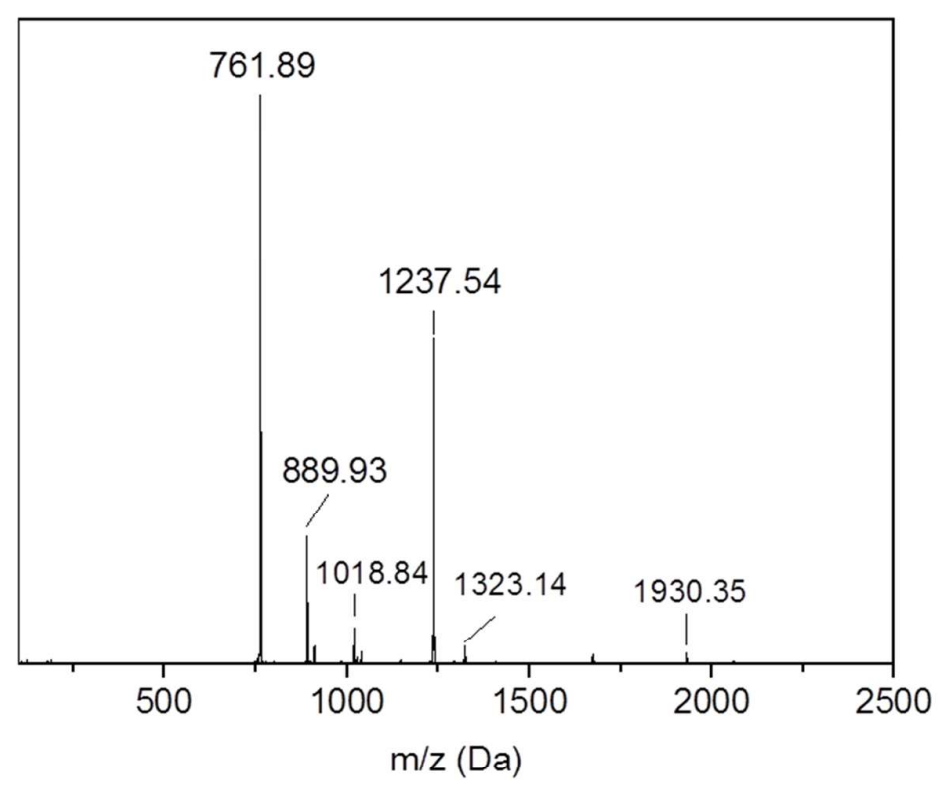

b)

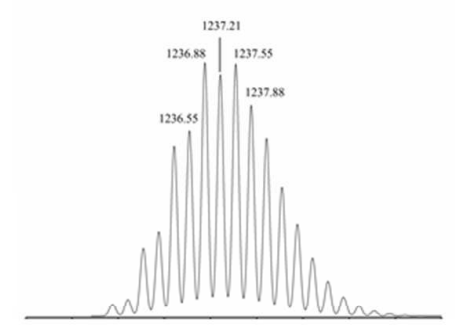

d)

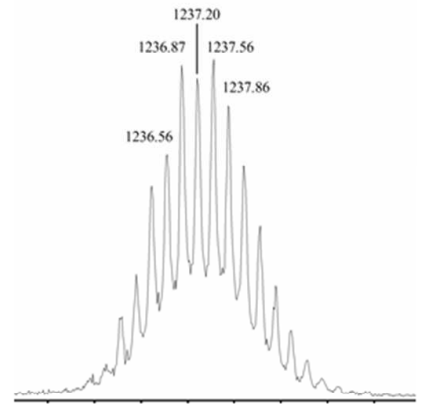

c)

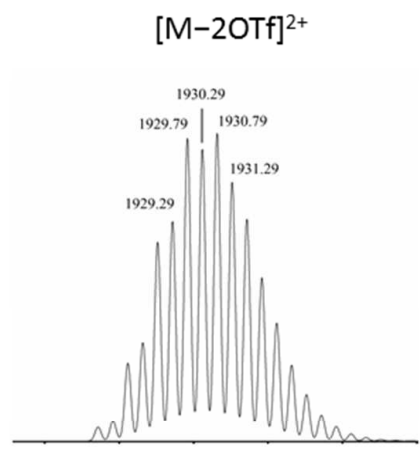

e)

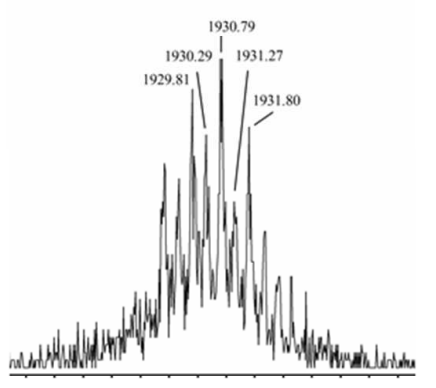

Figure S3. CSI-TOF-MS of complex 4. (a) full spectrum, theoretical (b, c) and S5 
experimental $(d, e)$ results of complex 4 . 


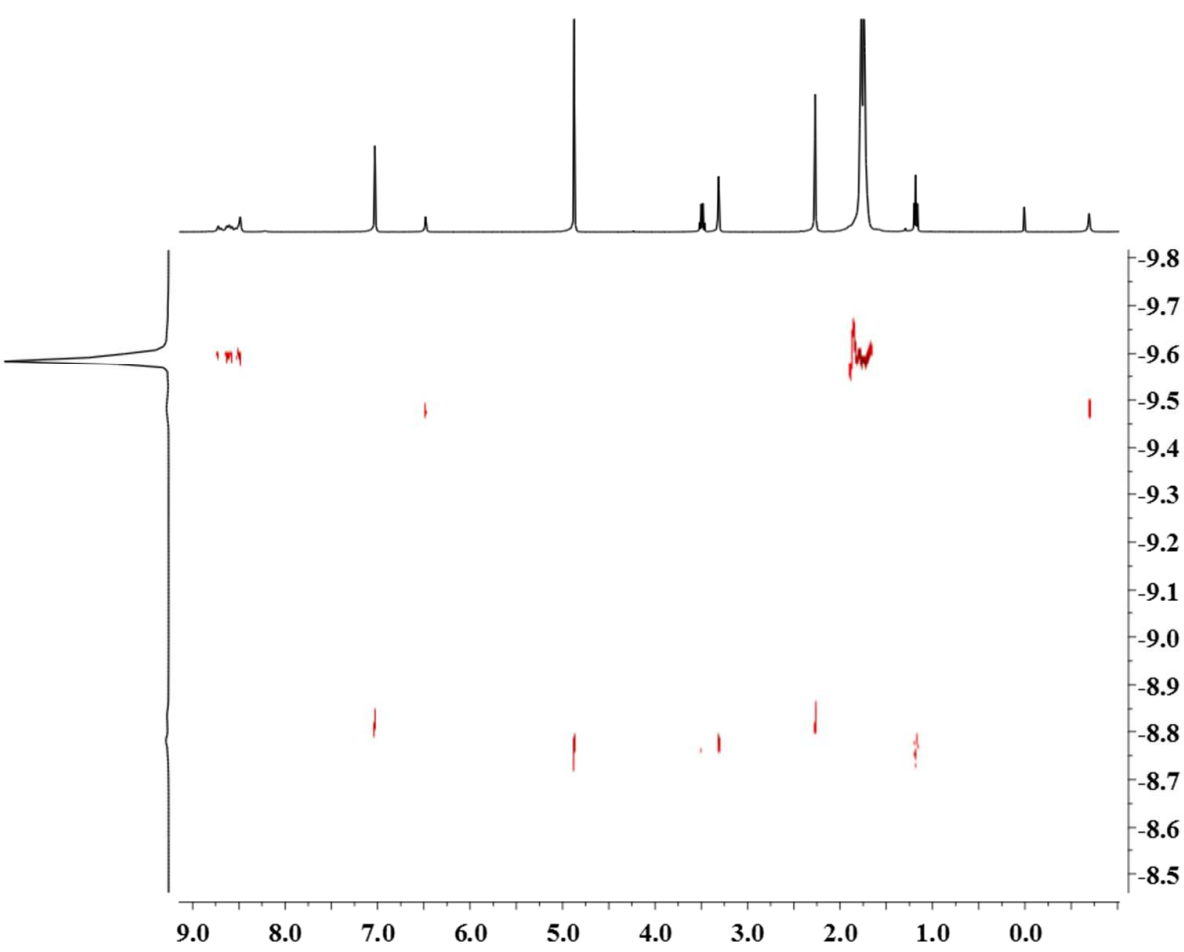

Figure S4. 2D DOSY NMR $\left(\mathrm{CD}_{3} \mathrm{OD}, 400 \mathrm{MHz}, 300 \mathrm{~K}\right.$, ppm) of complex $4(C=9.0 \mathrm{mM})$ in the presence of 4.0 equiv. of $p$-xylene.

Although the hydrodynamic radii for host $\mathbf{4}$ and encapsulated guest is not in a line, the hydrodynamic radii of encapsulated guest is obviously large than that in free guest. This phenomenon is proposed to interpret as different effects caused by the chemical exchange on chemical shift and self-diffusion coefficients values. see ref. Kharlamov, S. V., Ziganshina, A. Y., Aganov, A. V., Konovalov, A. I., Latypov, Sh. K. J. Inclusion Phenom. Macrocycl. Chem. 58,389 (2007). 


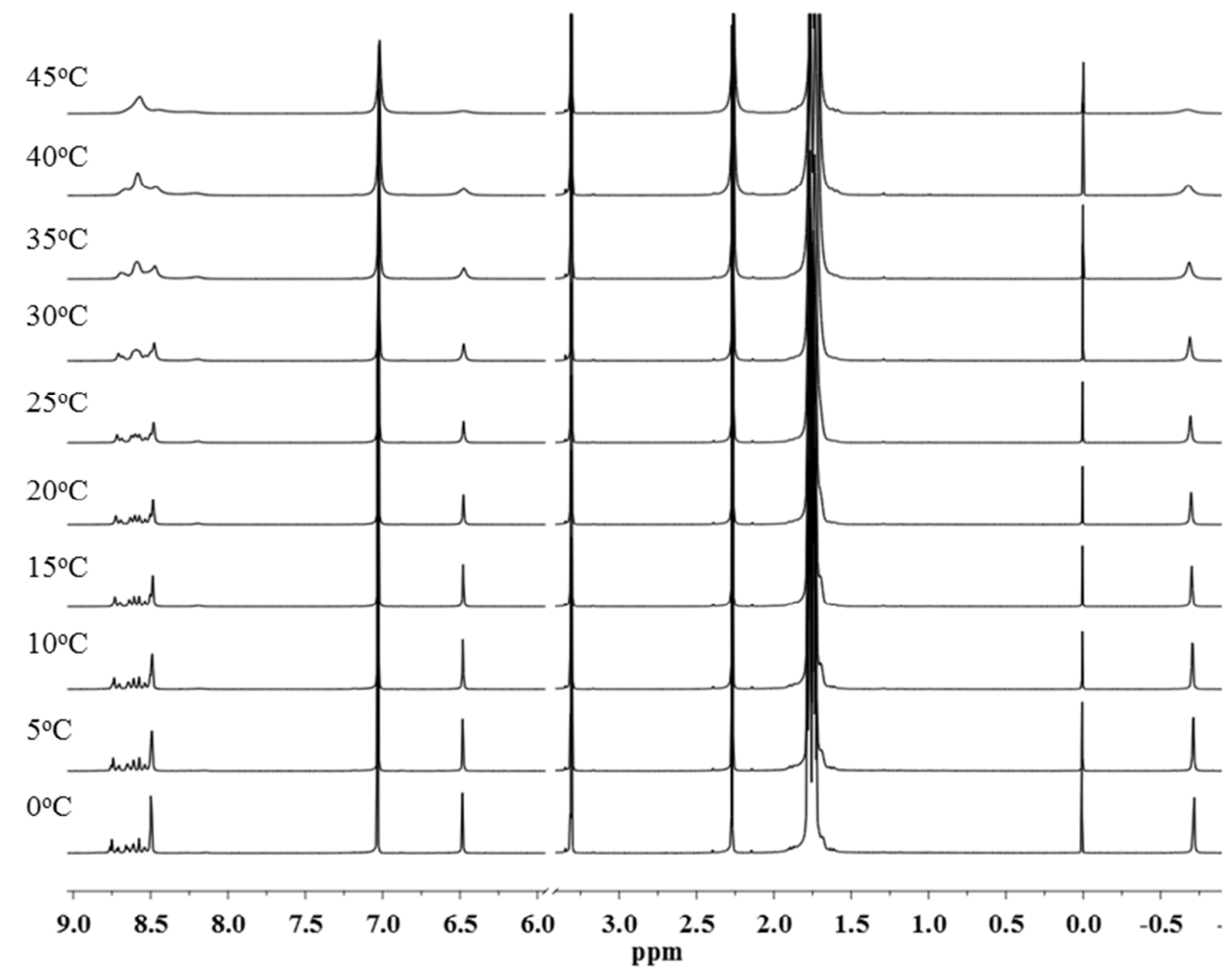

Figure S5. Variable-temperature ${ }^{1} \mathrm{H}$ NMR spectra on the titration complex 4 containing 4 equivalents of $p$-xylene. 


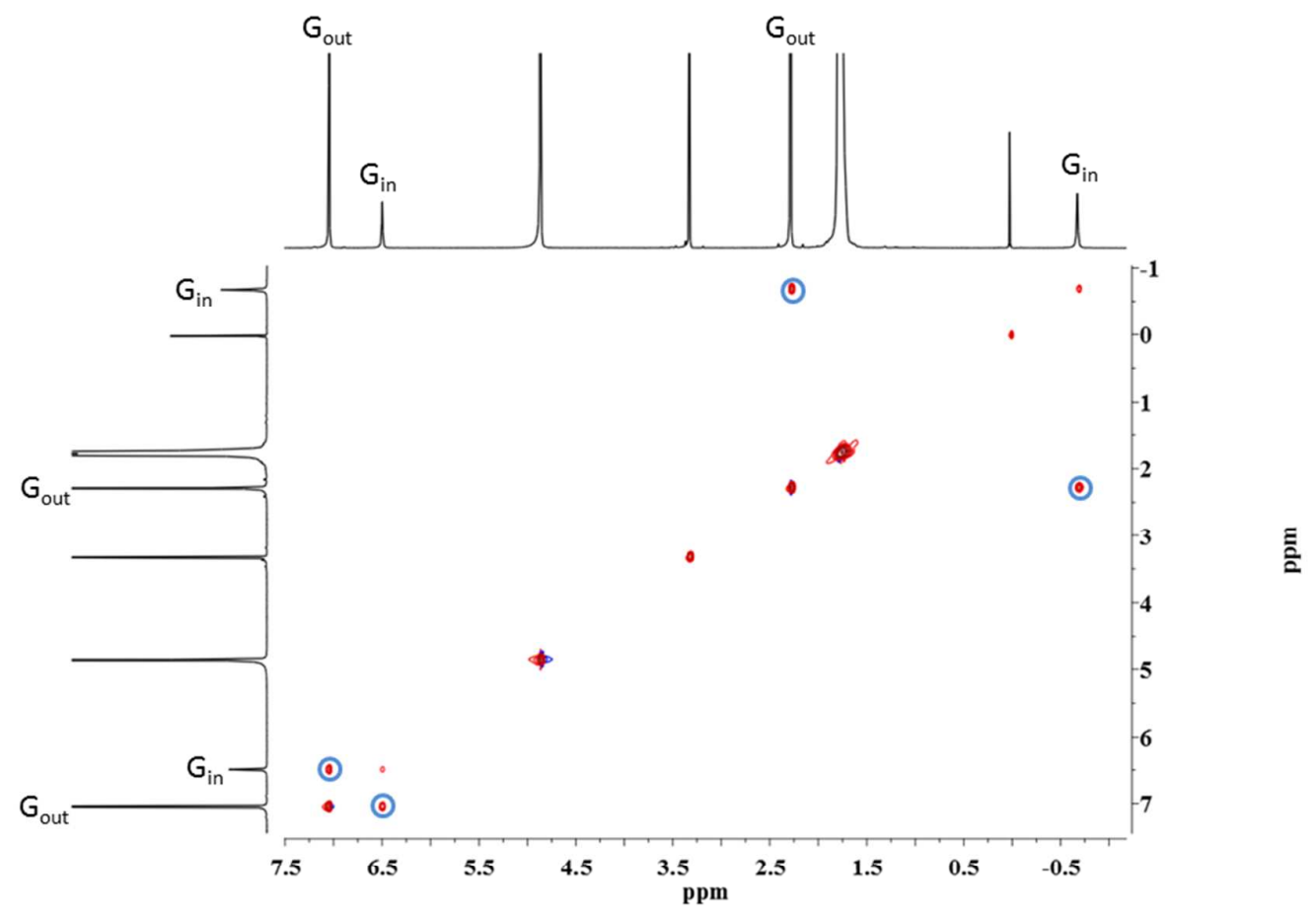

Figure S6. ${ }^{1} \mathrm{H}-{ }^{1} \mathrm{H}$ EXSY spectrum $\left(500 \mathrm{~Hz}, 298 \mathrm{~K}, \mathrm{CD}_{3} \mathrm{OD}\right.$, mixing time $\left.0.3 \mathrm{~s}\right)$ of 4 containing 4 equivalents of $p$-xylene. Exchange is observed between free guest and encapsulated guest. The rate constant could be determined via integration to $k_{\text {in }}=k_{\text {out }} \sim$ $1.27 \mathrm{~s}^{-1}$. 


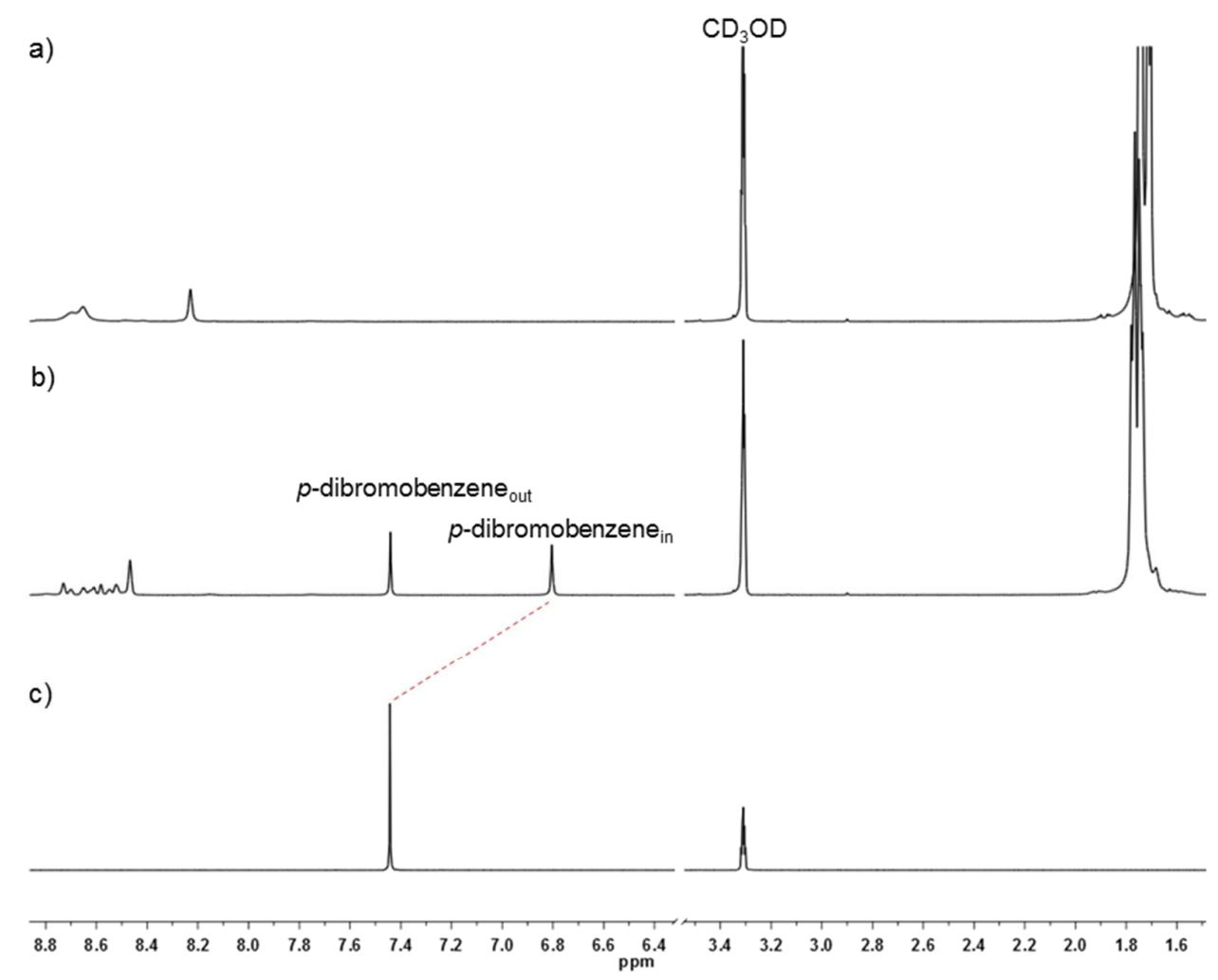

Figure S7. ${ }^{1} \mathrm{H}$ NMR spectra $(400 \mathrm{MHz}, 300 \mathrm{~K})$ of $\mathbf{4}(\mathrm{C}=4.5 \mathrm{mM})$ in the presence of (a) 0.0 , (b) 2.0 equiv. of $p$-dibromobenzene, and (c) only $p$-dibromobenzene in $\mathrm{CD}_{3} \mathrm{OD}$. 


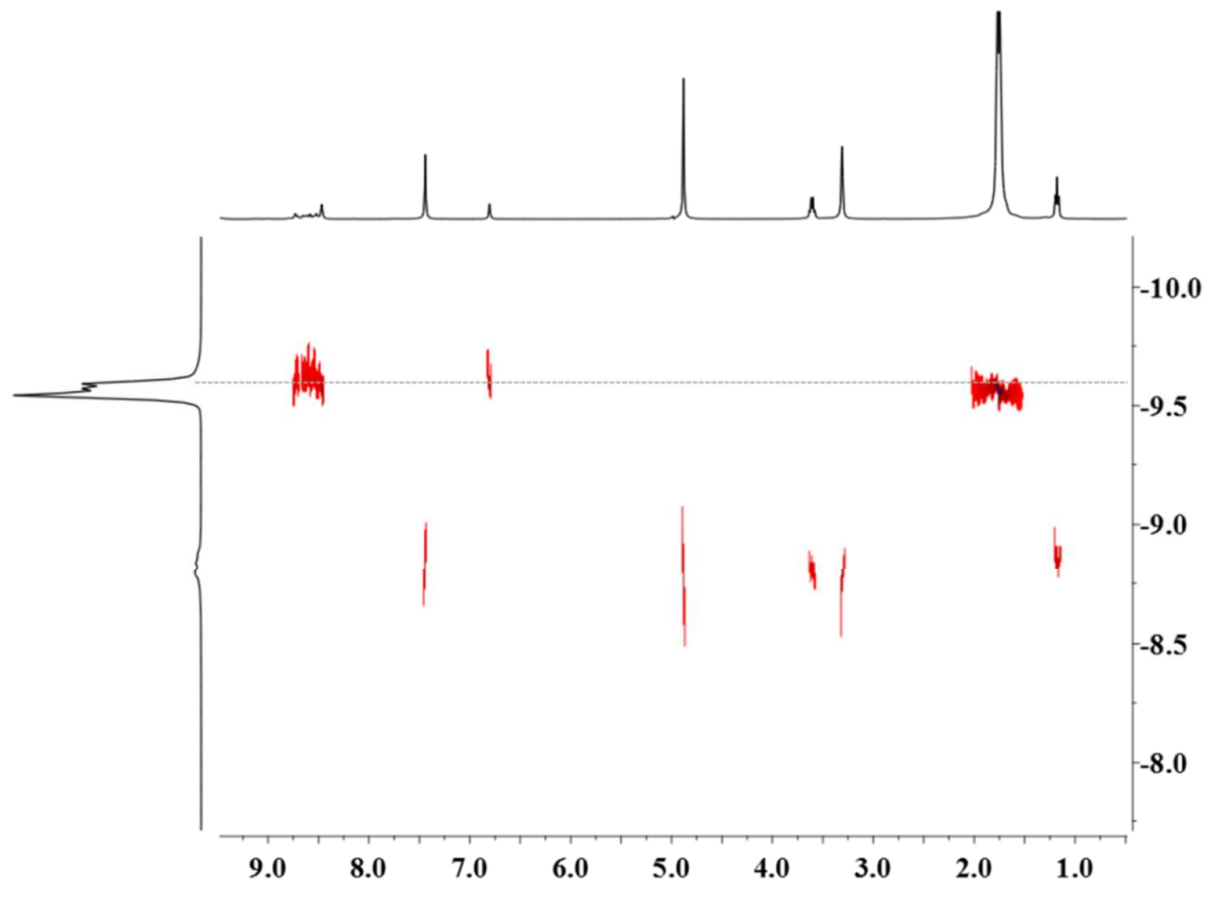

Figure S8. 2D DOSY NMR ( $\mathrm{CD}_{3} \mathrm{OD}, 400 \mathrm{MHz}, 300 \mathrm{~K}$, ppm) of complex $4(\mathrm{C}=4.5 \mathrm{mM})$ in the presence of 2.0 equiv. of $p$-dibromobenzene. 


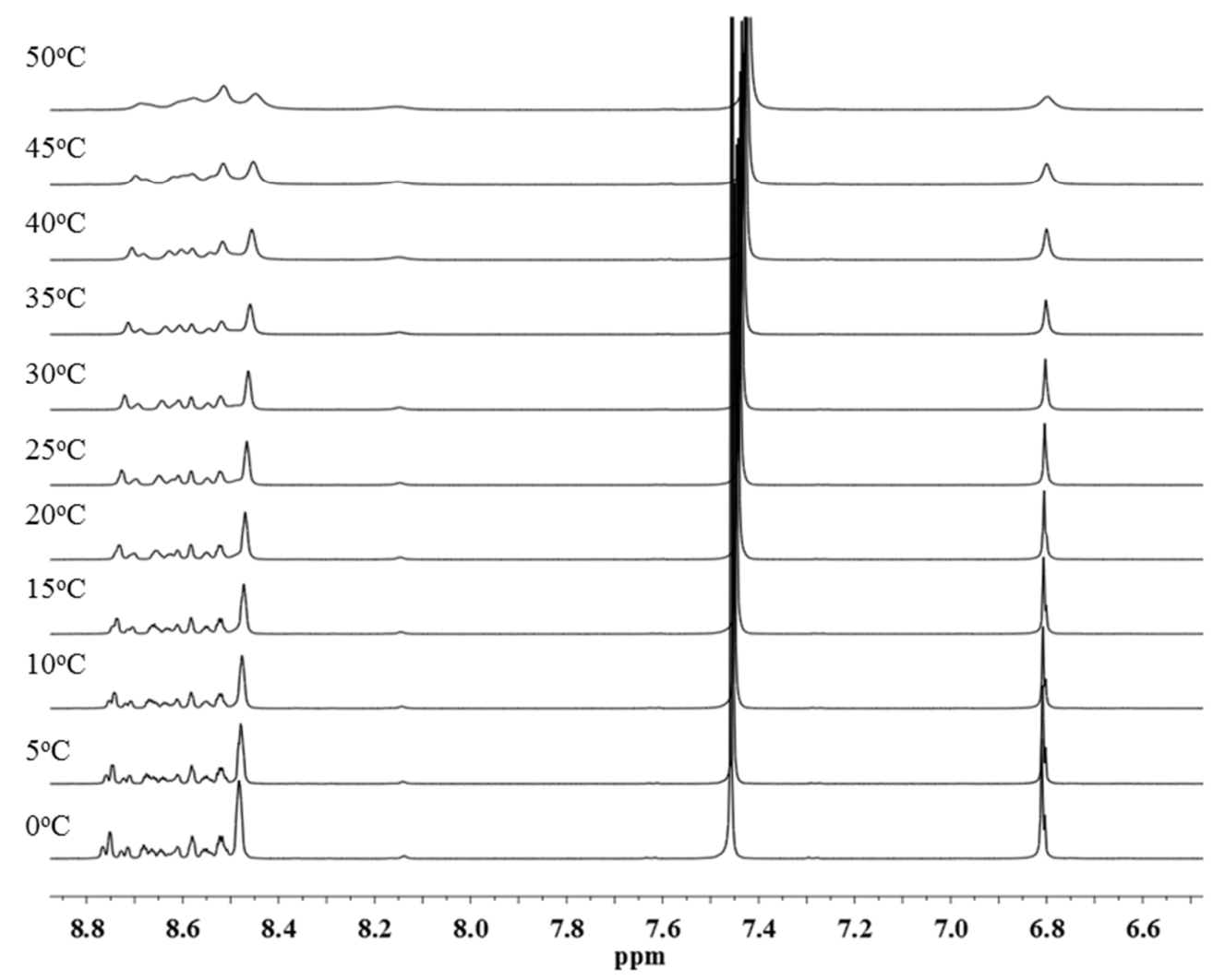

Figure S9. Variable-temperature ${ }^{1} \mathrm{H}$ NMR spectra (partial) on the titration complex 4 containing 2 equivalents of $p$-dibromobenzene. 


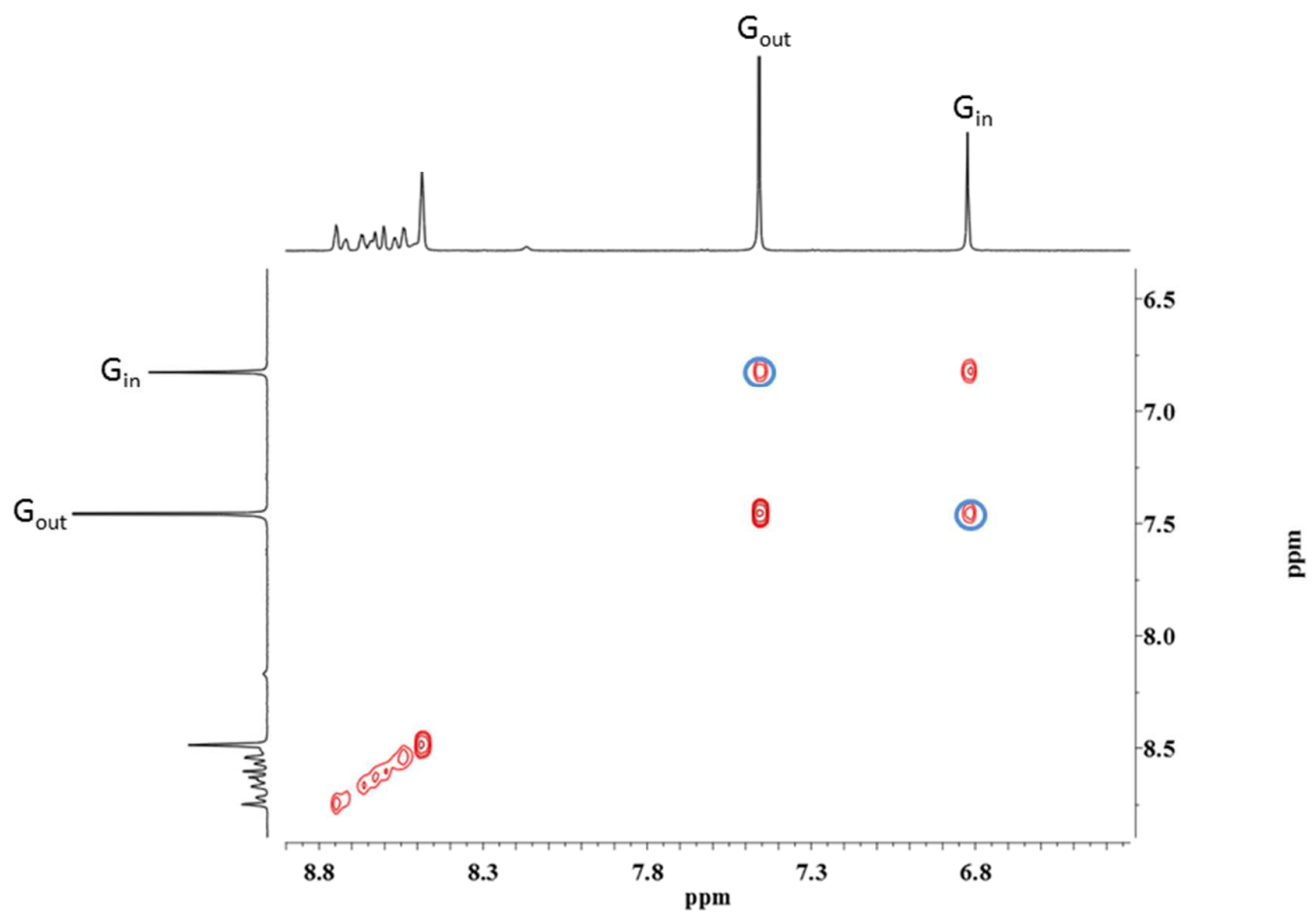

Figure S10. ${ }^{1} \mathrm{H}-{ }^{1} \mathrm{H}$ EXSY spectrum $\left(500 \mathrm{~Hz}, 298 \mathrm{~K}, \mathrm{CD}_{3} \mathrm{OD}\right.$, mixing time $\left.0.3 \mathrm{~s}\right)$ of 4 containing 2 equivalents of $p$-dibromobenzene. Exchange is observed between free guest and encapsulated guest. The rate constant could be determined via integration to $k_{\text {in }}=k_{\text {out }}$ $\sim 0.79 \mathrm{~s}^{-1}$. 
a)

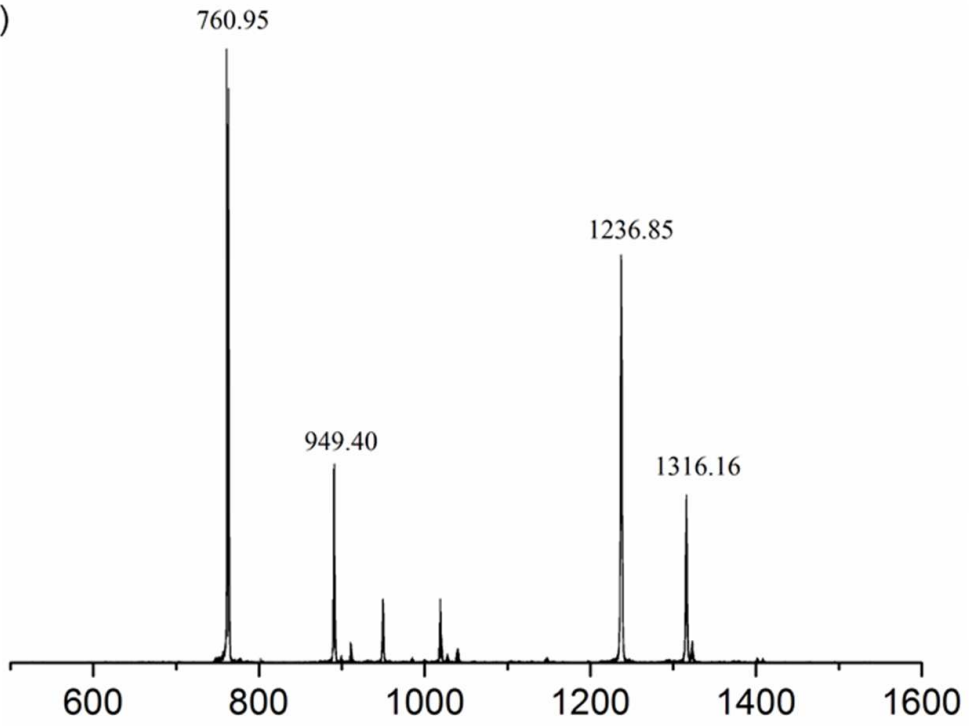

b)

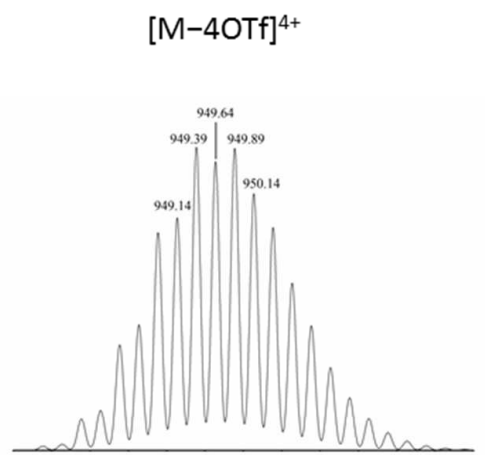

d)

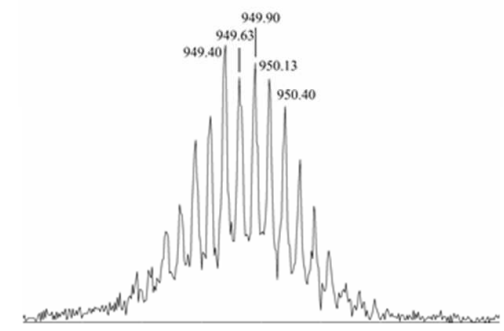

c)

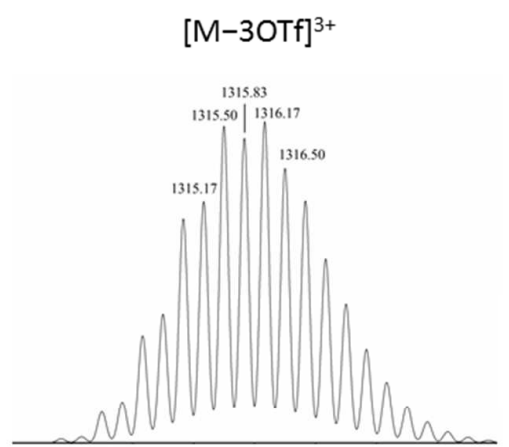

e)

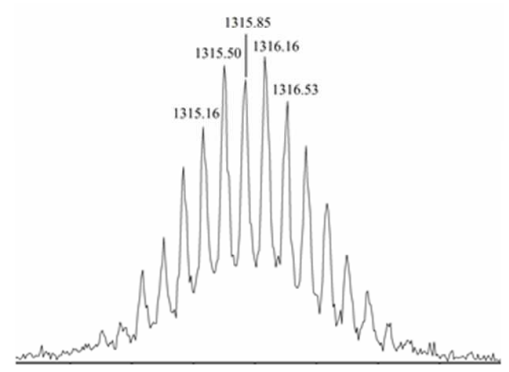

Figure S11. CSI-TOF-MS of complex p-dibromobenzenec4. (a) full spectrum, theoretical S14 
(b, c) and experimental (d, e) results of complex p-dibromobenzenec4.

a)

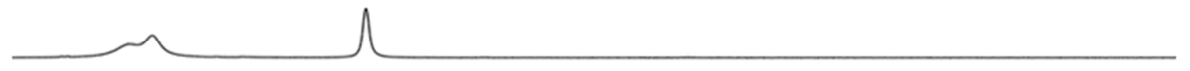

b)

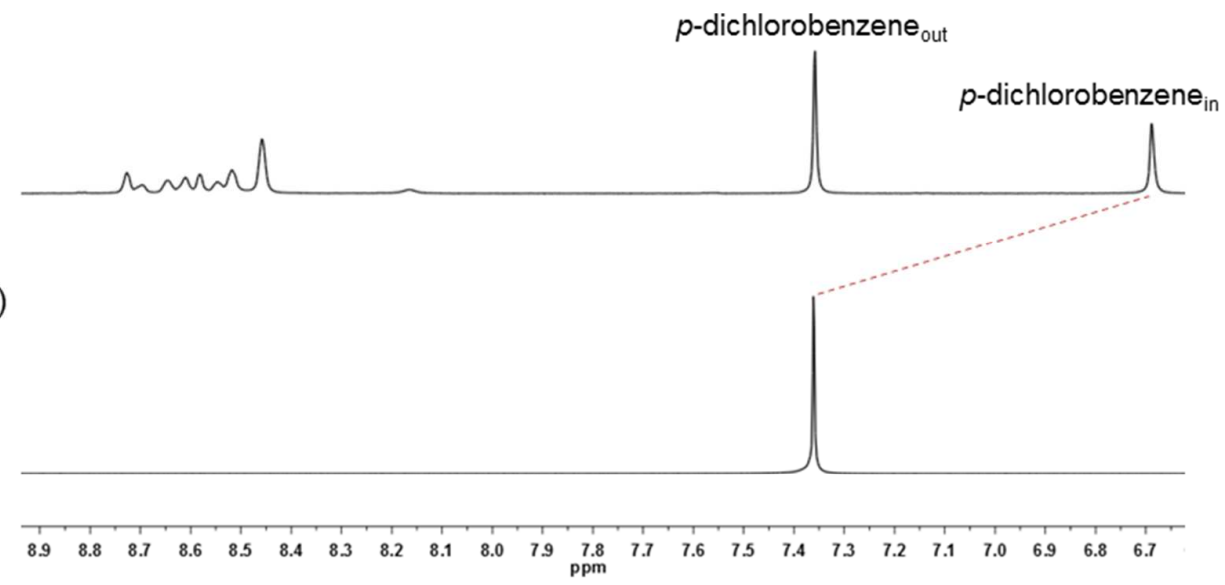

Figure S12. ${ }^{1} \mathrm{H}$ NMR $\left(\mathrm{CD}_{3} \mathrm{OD}, 400 \mathrm{MHz}, 300 \mathrm{~K}\right.$, ppm) of complex $4(C=4.5 \mathrm{mM})$ in the presence of (a) 0.0, (b) 2.5 equiv. of $p$-dichlorobenzene, and (c) only $p$-dichlorobenzene in $\mathrm{CD}_{3} \mathrm{OD}$. 


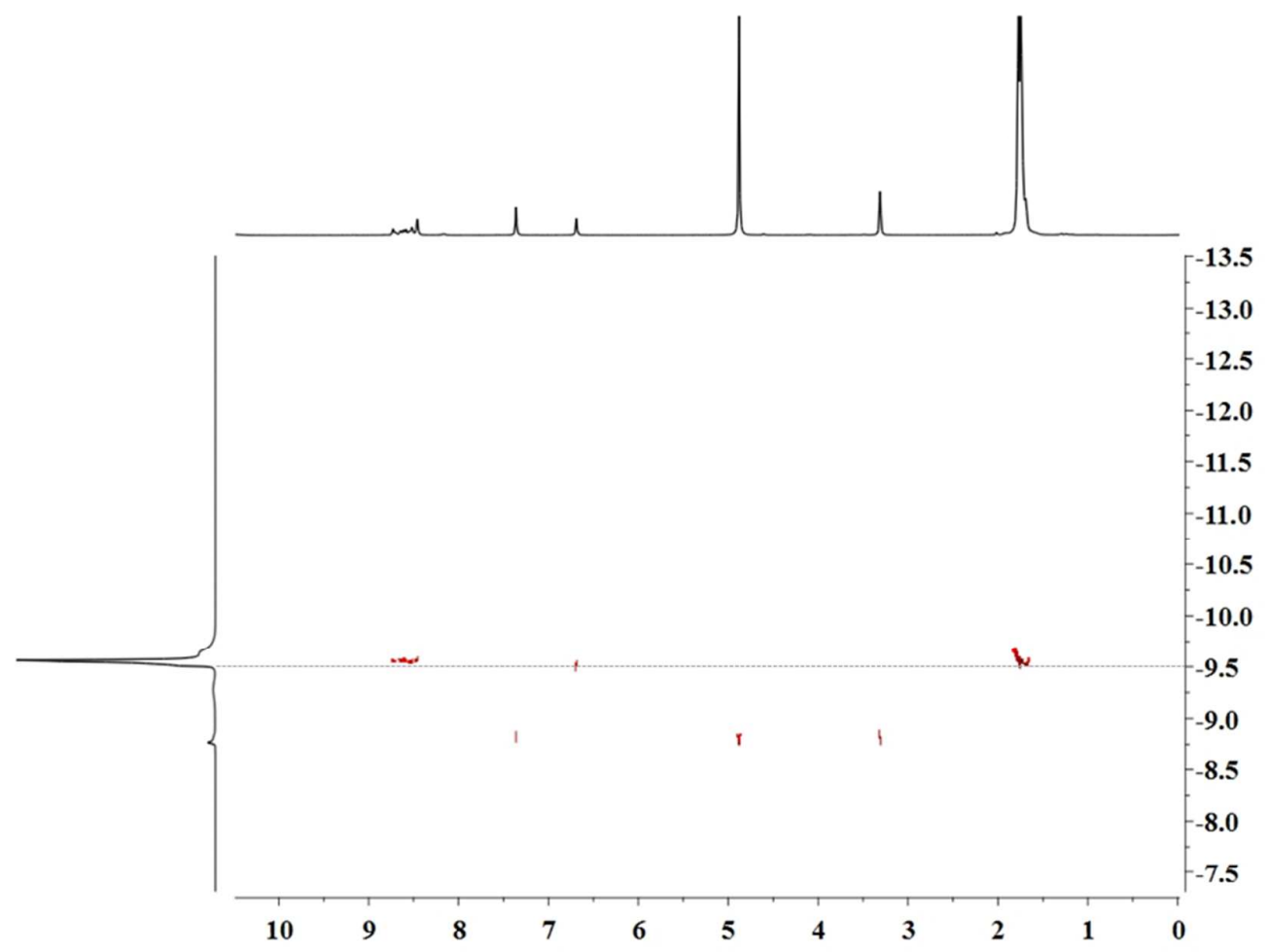

Figure S13. 2D DOSY NMR ( $\left.\mathrm{CD}_{3} \mathrm{OD}, 400 \mathrm{MHz}, 300 \mathrm{~K}, \mathrm{ppm}\right)$ of complex $4(\mathrm{C}=4.5 \mathrm{mM})$ in the presence of 2.5 equiv. of $p$-dichlorobenzene. 
a)

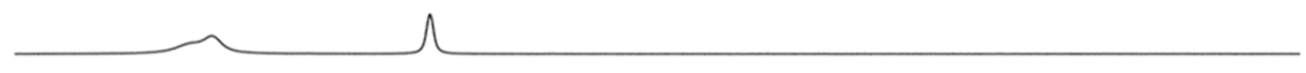

b)

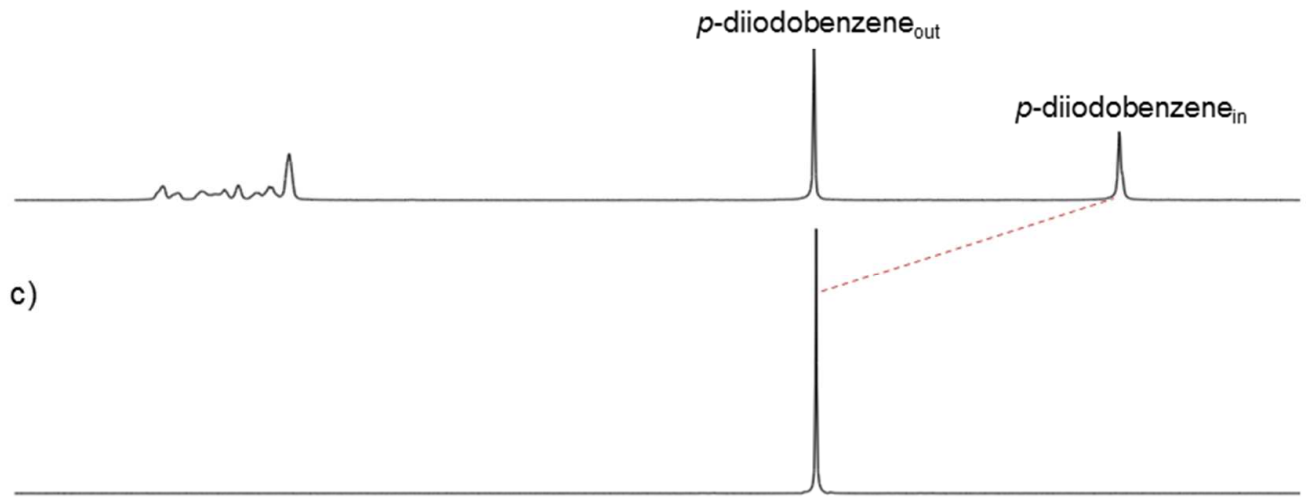

$\begin{array}{lllllllllllllllllllllllllllll}9.0 & 8.9 & 8.8 & 8.7 & 8.6 & 8.5 & 8.4 & 8.3 & 8.2 & 8.1 & 8.0 & 7.9 & 7.8 & 7.7 & 7.6 & 7.5 & 7.4 & 7.3 & 7.2 & 7.1 & 7.0 & 6.9 & 6.8 & 6.7 & 6.6\end{array}$

Figure S14. ${ }^{1} \mathrm{H}$ NMR $\left(\mathrm{CD}_{3} \mathrm{OD}, 400 \mathrm{MHz}, 300 \mathrm{~K}\right.$, ppm) of complex $4(C=4.5 \mathrm{mM})$ in the presence of (a) 0.0 , (b) 2.2 equiv. of $p$-diiodobenzene, and (c) only p-diiodobenzene in $\mathrm{CD}_{3} \mathrm{OD}$. 


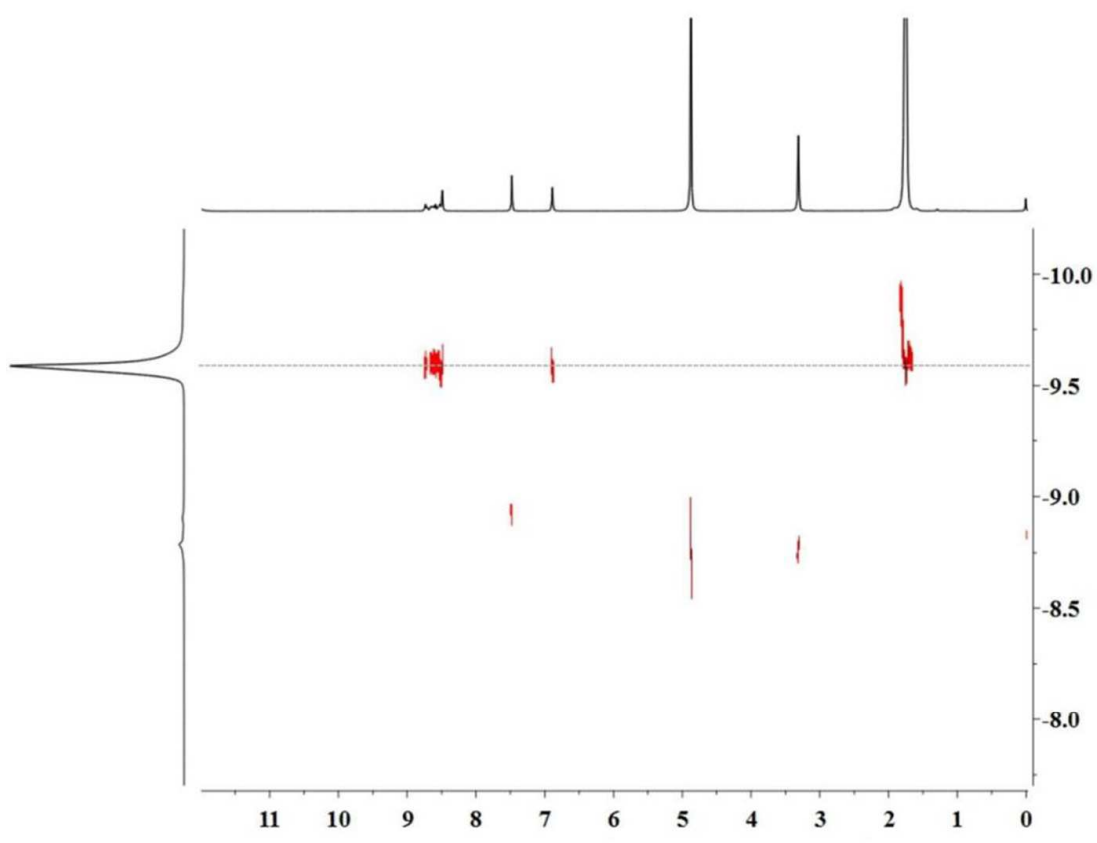

Figure S15. 2D DOSY NMR ( $\mathrm{CD}_{3} \mathrm{OD}, 400 \mathrm{MHz}, 300 \mathrm{~K}$, ppm) of complex $4(\mathrm{C}=4.5 \mathrm{mM})$ in the presence of 2.2 equiv. of $p$-diiodobenzene. 


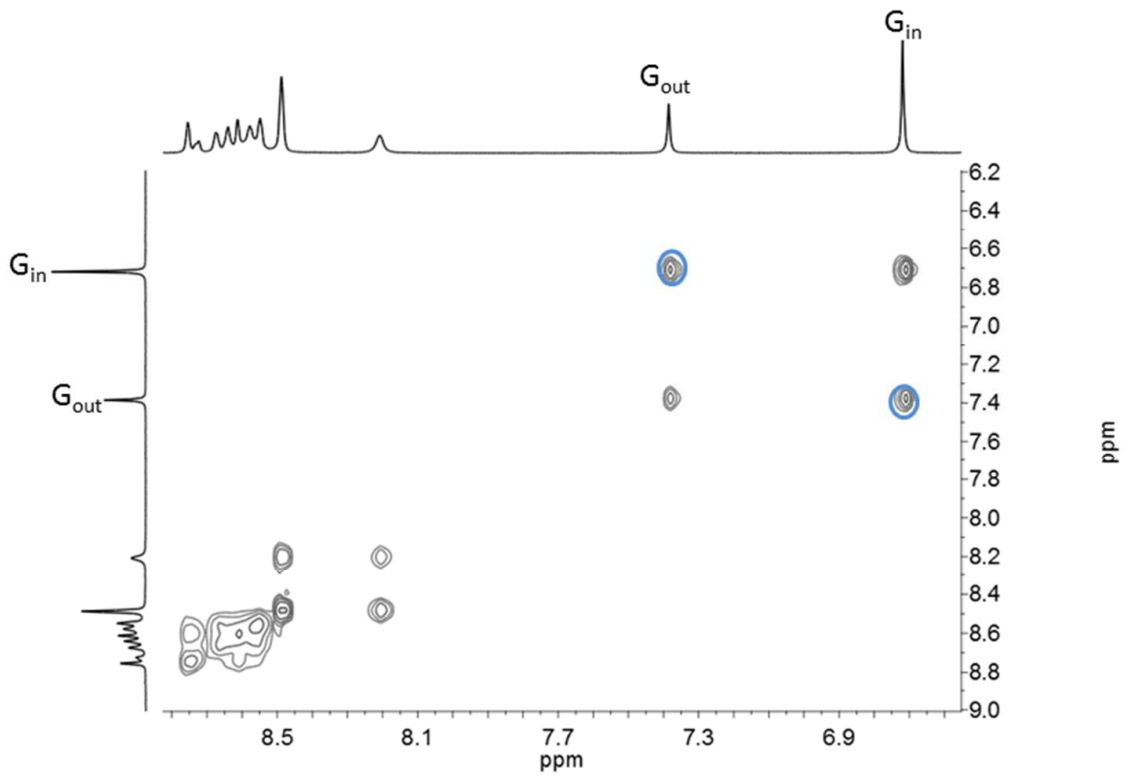

Figure S16. ${ }^{1} \mathrm{H}-{ }^{1} \mathrm{H}$ EXSY spectrum $\left(500 \mathrm{~Hz}, 298 \mathrm{~K}, \mathrm{CD}_{3} \mathrm{OD}\right.$, mixing time $\left.0.3 \mathrm{~s}\right)$ of 4 containing one equivalent of $p$-dichlorobenzene. Exchange is observed between free guest and encapsulated guest. The rate constant could be determined via integration to $k_{\text {in }}=k_{\text {out }} \sim 3.06 \mathrm{~s}^{-1}$. 


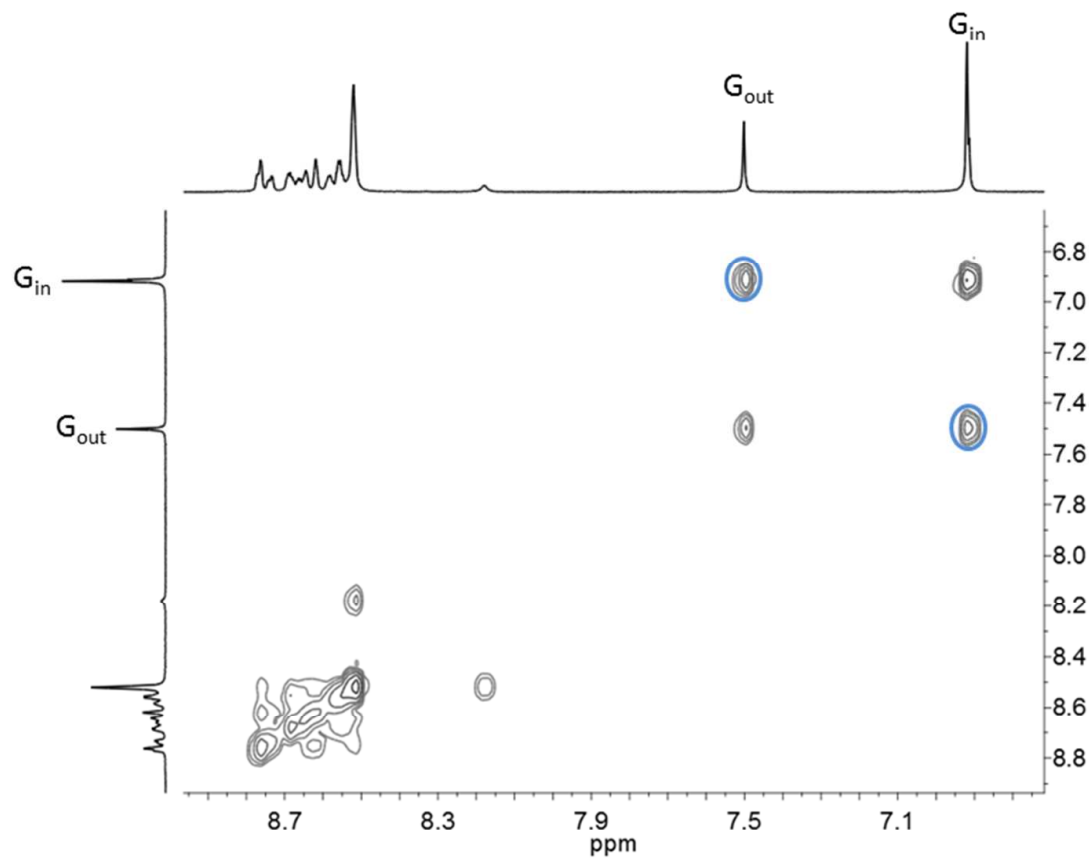

흠

Figure S17. ${ }^{1} \mathrm{H}-{ }^{1} \mathrm{H}$ EXSY spectrum $\left(500 \mathrm{~Hz}, 298 \mathrm{~K}, \mathrm{CD}_{3} \mathrm{OD}\right.$, mixing time $\left.0.3 \mathrm{~s}\right)$ of 4 containing one equivalent of $p$-diiodobenzene. Exchange is observed between free guest and encapsulated guest. The rate constant could be determined via integration to $k_{\text {in }}=k_{\text {out }}$ $\sim 1.65 \mathrm{~s}^{-1}$. 


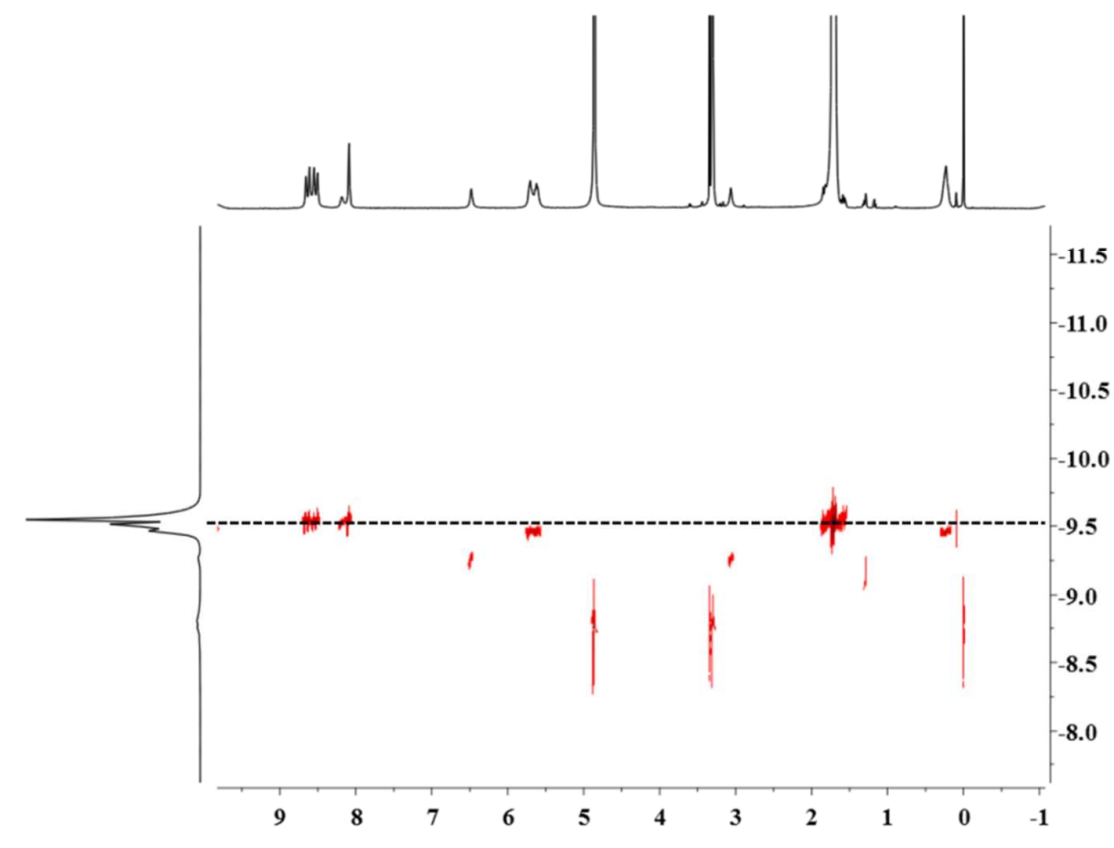

Figure S18. 2D DOSY NMR ( $\mathrm{CD}_{3} \mathrm{OD}, 400 \mathrm{MHz}, 300 \mathrm{~K}$, ppm) of complex $4(\mathrm{C}=4.5 \mathrm{mM})$ in the presence of 3.0 equiv. of $p C p$. 


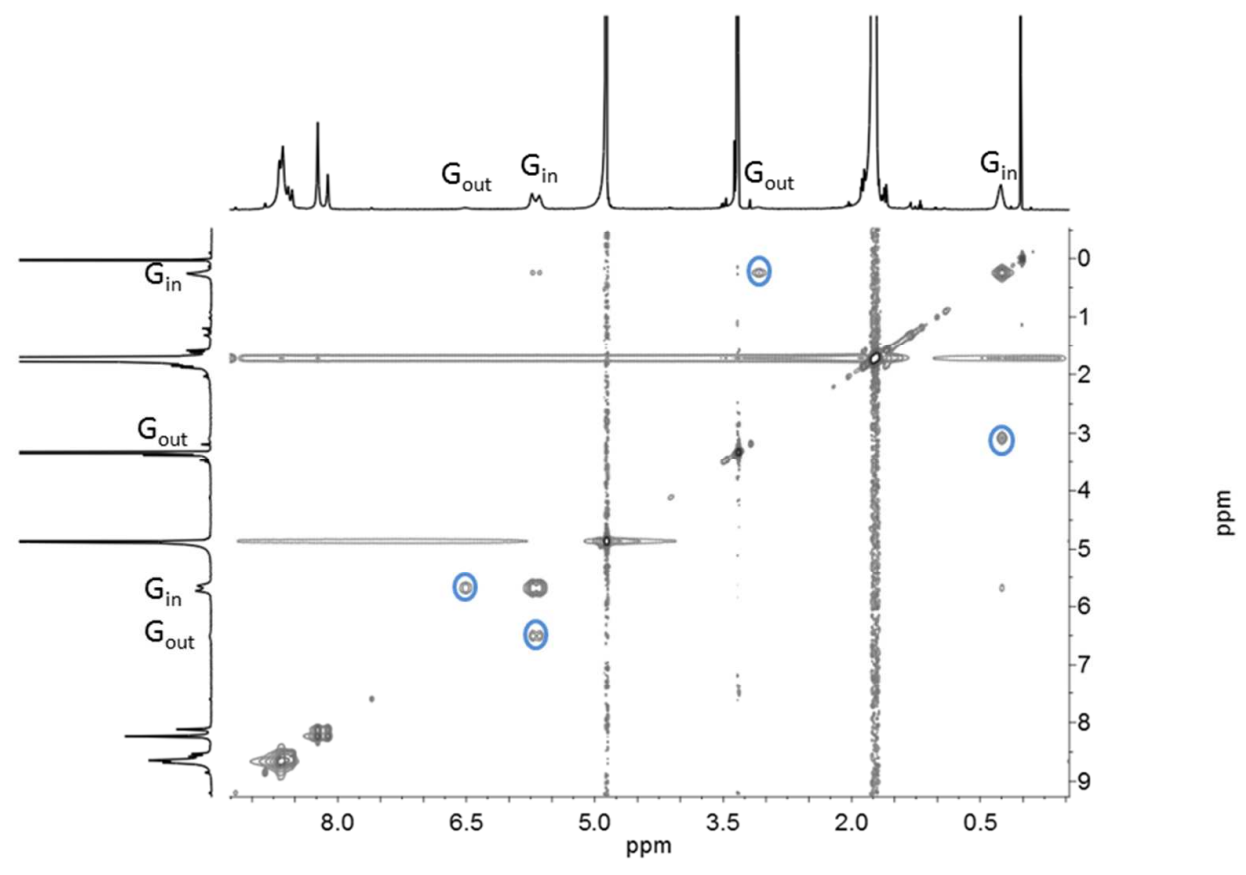

Figure S19. ${ }^{1} \mathrm{H}-{ }^{1} \mathrm{H}$ EXSY spectrum $\left(500 \mathrm{~Hz}, 298 \mathrm{~K}, \mathrm{CD}_{3} \mathrm{OD}\right.$, mixing time $\left.0.3 \mathrm{~s}\right)$ of 4 containing one equivalent of $\mathrm{pCp}$. Exchange is observed between free guest and encapsulated guest. The rate constant could be determined via integration to $k_{\text {in }}=k_{\text {out }} \sim$ $0.68 \mathrm{~s}^{-1}$. 


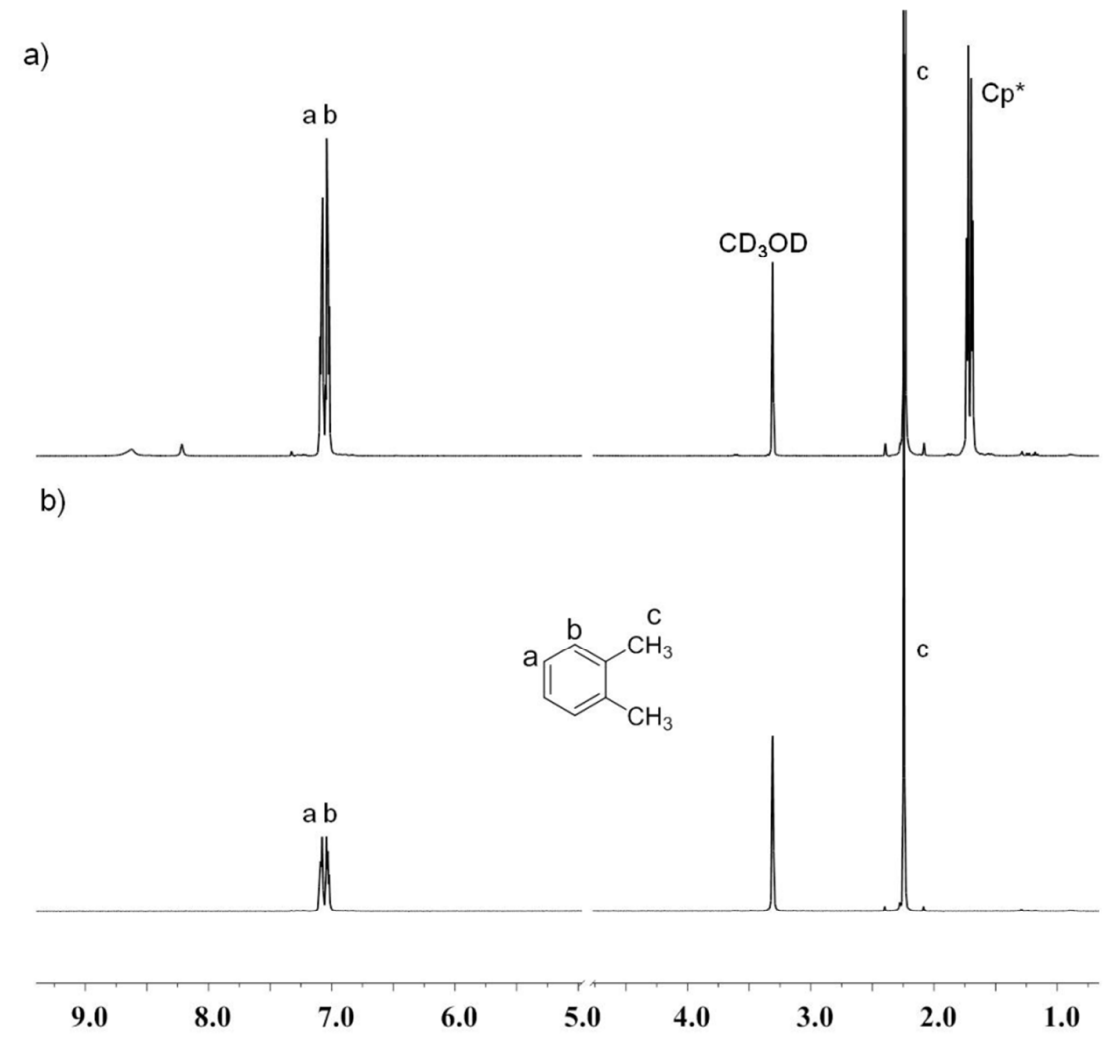

Figure S20. ${ }^{1} \mathrm{H} \mathrm{NMR}\left(\mathrm{CD}_{3} \mathrm{OD}, 400 \mathrm{MHz}, 300 \mathrm{~K}\right.$, ppm) of $(\mathrm{a})$ complex $4(C=3.1 \mathrm{mM})$ in the presence of 30.0 equiv. of o-xylene; (b) o-xylene alone in $\mathrm{CD}_{3} \mathrm{OD}$. 


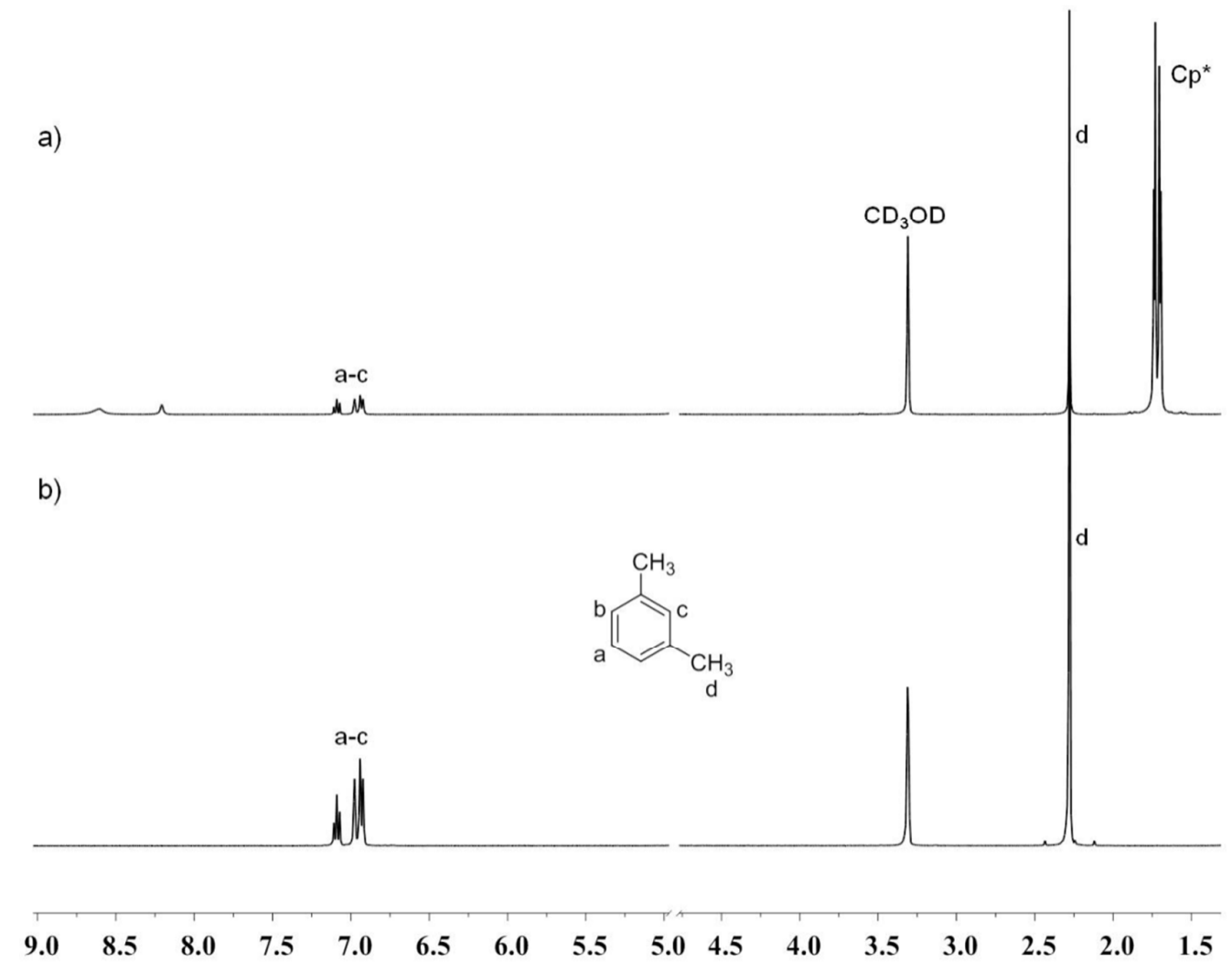

Figure S21. ${ }^{1} \mathrm{H} \mathrm{NMR}\left(\mathrm{CD}_{3} \mathrm{OD}, 400 \mathrm{MHz}, 300 \mathrm{~K}, \mathrm{ppm}\right)$ of $(\mathrm{a})$ complex $4(C=3.1 \mathrm{mM})$ in the presence of 3.0 equiv. of $m$-xylene; (b) $m$-xylene alone in $\mathrm{CD}_{3} \mathrm{OD}$. 
a)

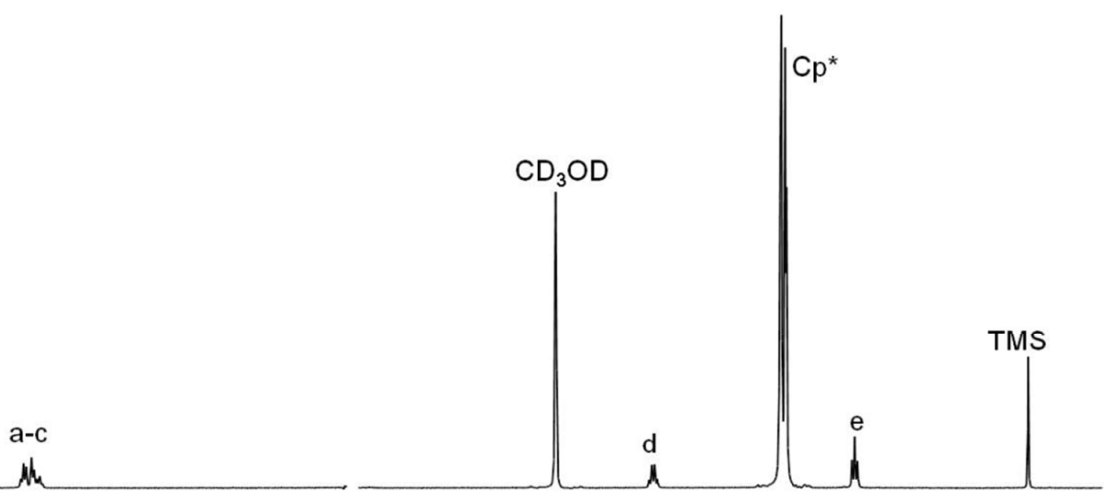

b)

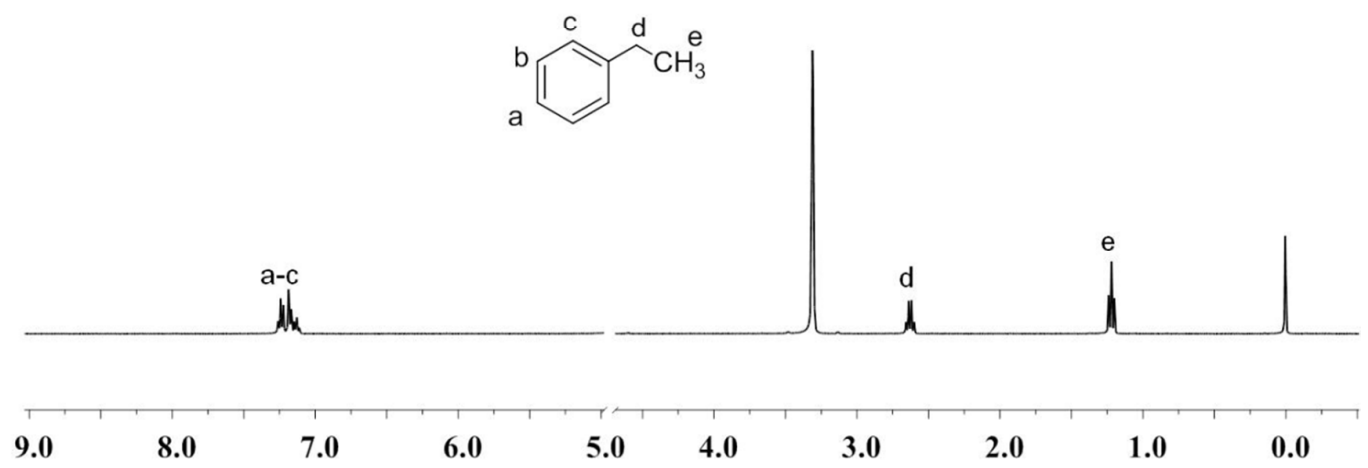

Figure S22. ${ }^{1} \mathrm{H}$ NMR $\left(\mathrm{CD}_{3} \mathrm{OD}, 400 \mathrm{MHz}, 300 \mathrm{~K}, \mathrm{ppm}\right)$ of $(\mathrm{a})$ complex $4(C=3.1 \mathrm{mM})$ in the presence of 3.0 equiv. of ethylenzene; (b) ethylenzene alone in $\mathrm{CD}_{3} \mathrm{OD}$. 
a)

b)

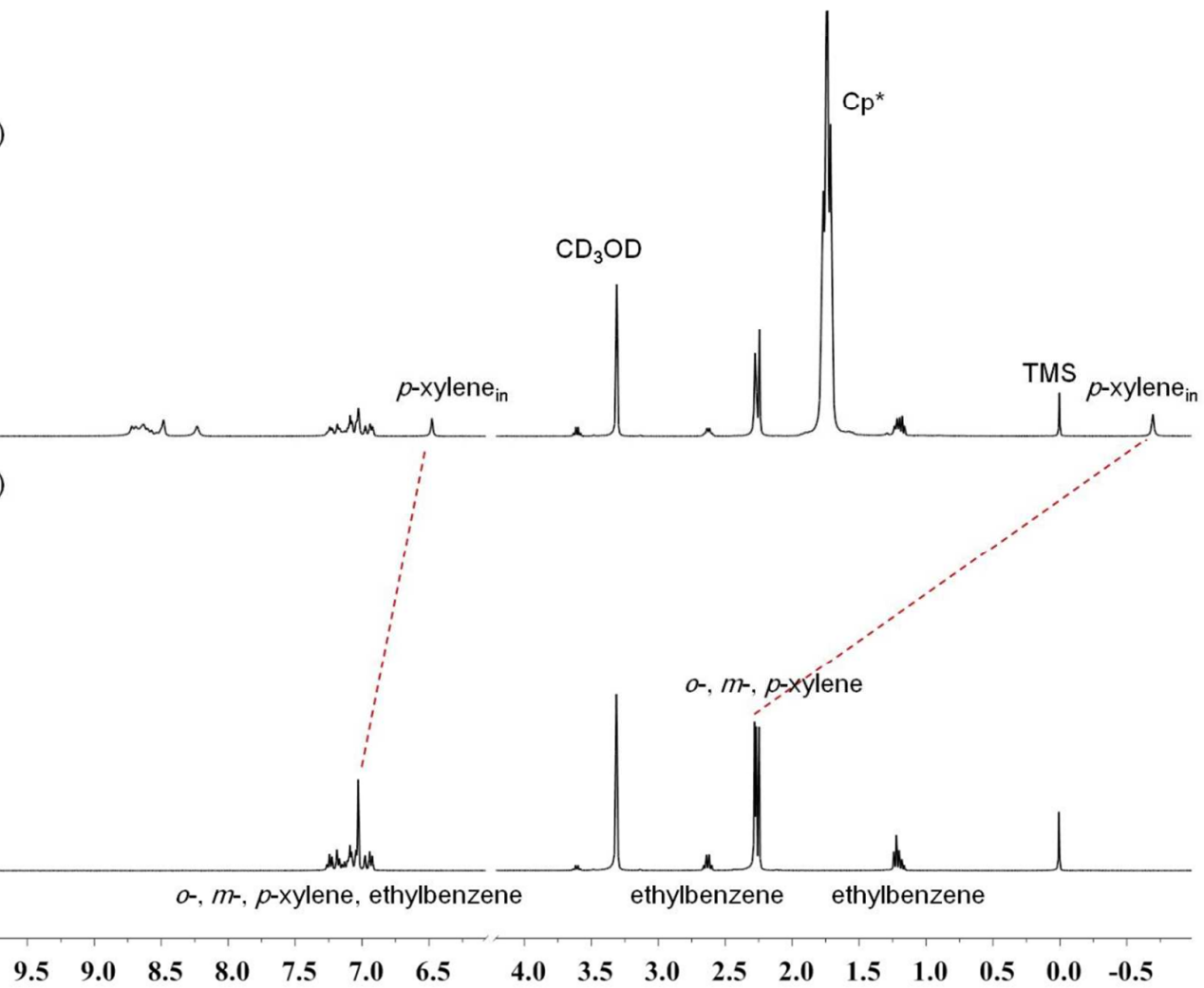

Figure S23. ${ }^{1} \mathrm{H} N M R\left(\mathrm{CD}_{3} \mathrm{OD}, 400 \mathrm{MHz}, 300 \mathrm{~K}\right.$, ppm) of (a) complex $4(\mathrm{C}=3.8 \mathrm{mM})$ in the presence of $p$-xylene, $m$-xylene, $o$-xylene and ethylbenzene (molar ratio $=1: 1.5: 1: .5$ : $1.5: 1.5)$; (b) o-, $m$-, $p$-dibromobenzene and ethylbenzene (molar ratio $=1: 1: 1: 1$ ) in $\mathrm{CD}_{3} \mathrm{OD}$. 
a)

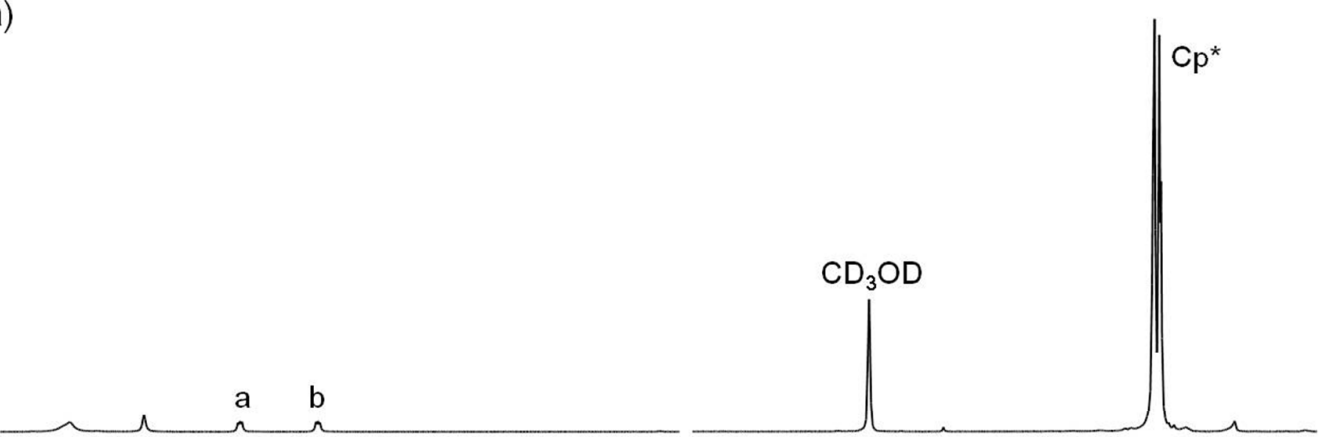

b)

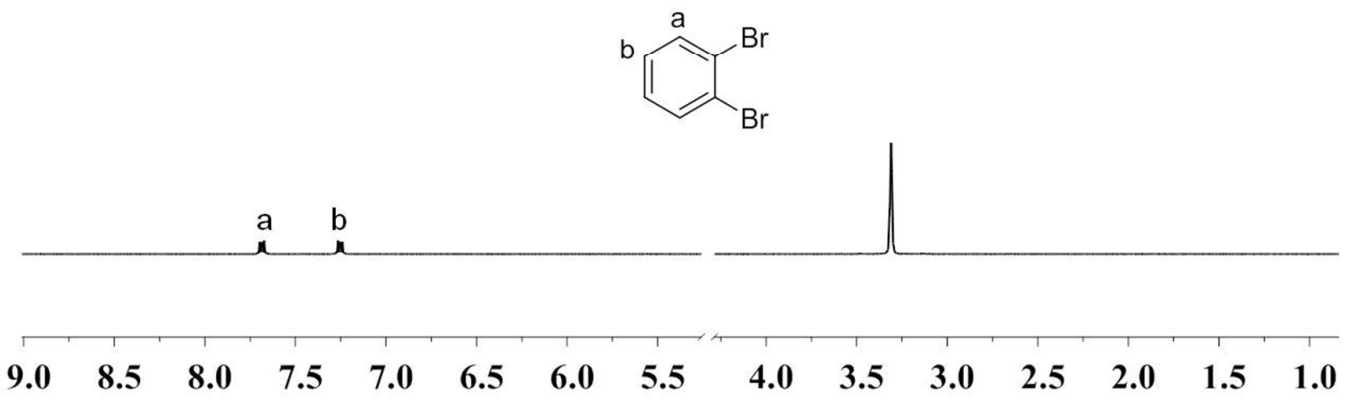

Figure S24. ${ }^{1} \mathrm{H}$ NMR $\left(\mathrm{CD}_{3} \mathrm{OD}, 400 \mathrm{MHz}, 300 \mathrm{~K}\right.$, ppm) for (a) complex $4(\mathrm{C}=4.5 \mathrm{mM})$ in the presence of 1.0 equiv. of o-dibromobenzene; (b) o-dibromobenzene alone in $\mathrm{CD}_{3} \mathrm{OD}$. 
a)

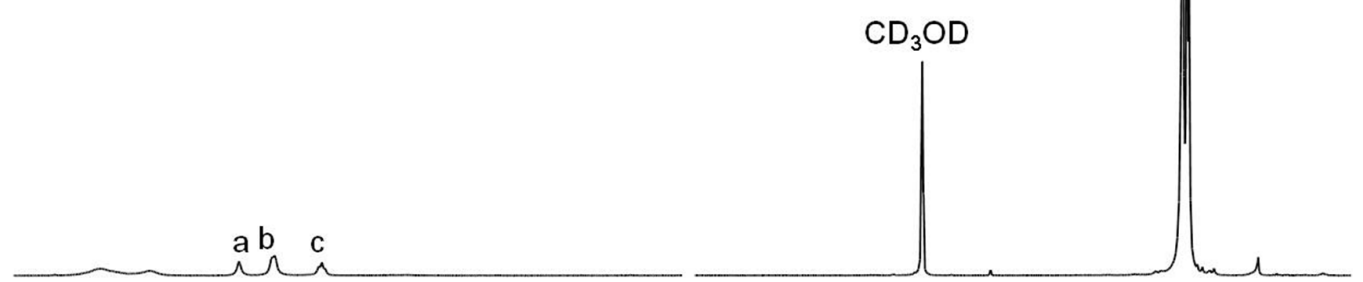

b)

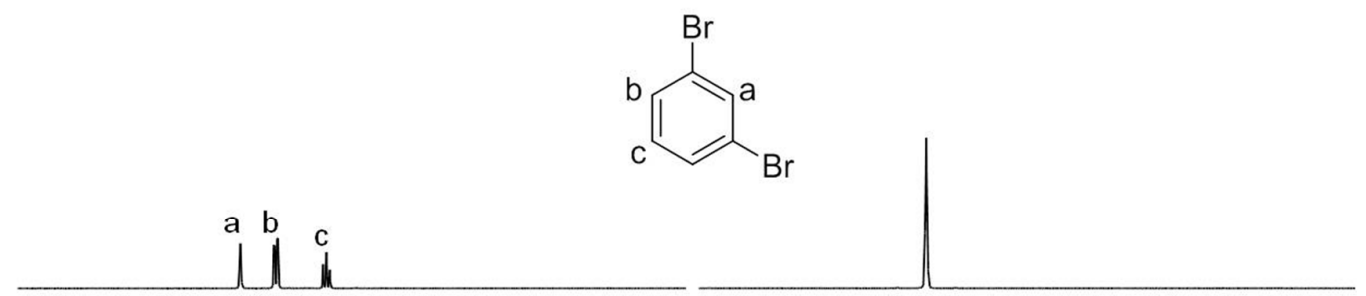

\section{$\begin{array}{llllllllllllllll}9.0 & 8.5 & 8.0 & 7.5 & 7.0 & 6.5 & 6.0 & 5.5 & 4.5 & 4.0 & 3.5 & 3.0 & 2.5 & 2.0 & 1.5 & 1.0\end{array}$}

Figure S25. ${ }^{1} \mathrm{H}$ NMR $\left(\mathrm{CD}_{3} \mathrm{OD}, 400 \mathrm{MHz}, 300 \mathrm{~K}\right.$, ppm) for (a) complex $4(C=4.5 \mathrm{mM})$ in the presence of 1.0 equiv. of $m$-dibromobenzene; (b) $m$-dibromobenzene alone in $\mathrm{CD}_{3} \mathrm{OD}$. 
a)
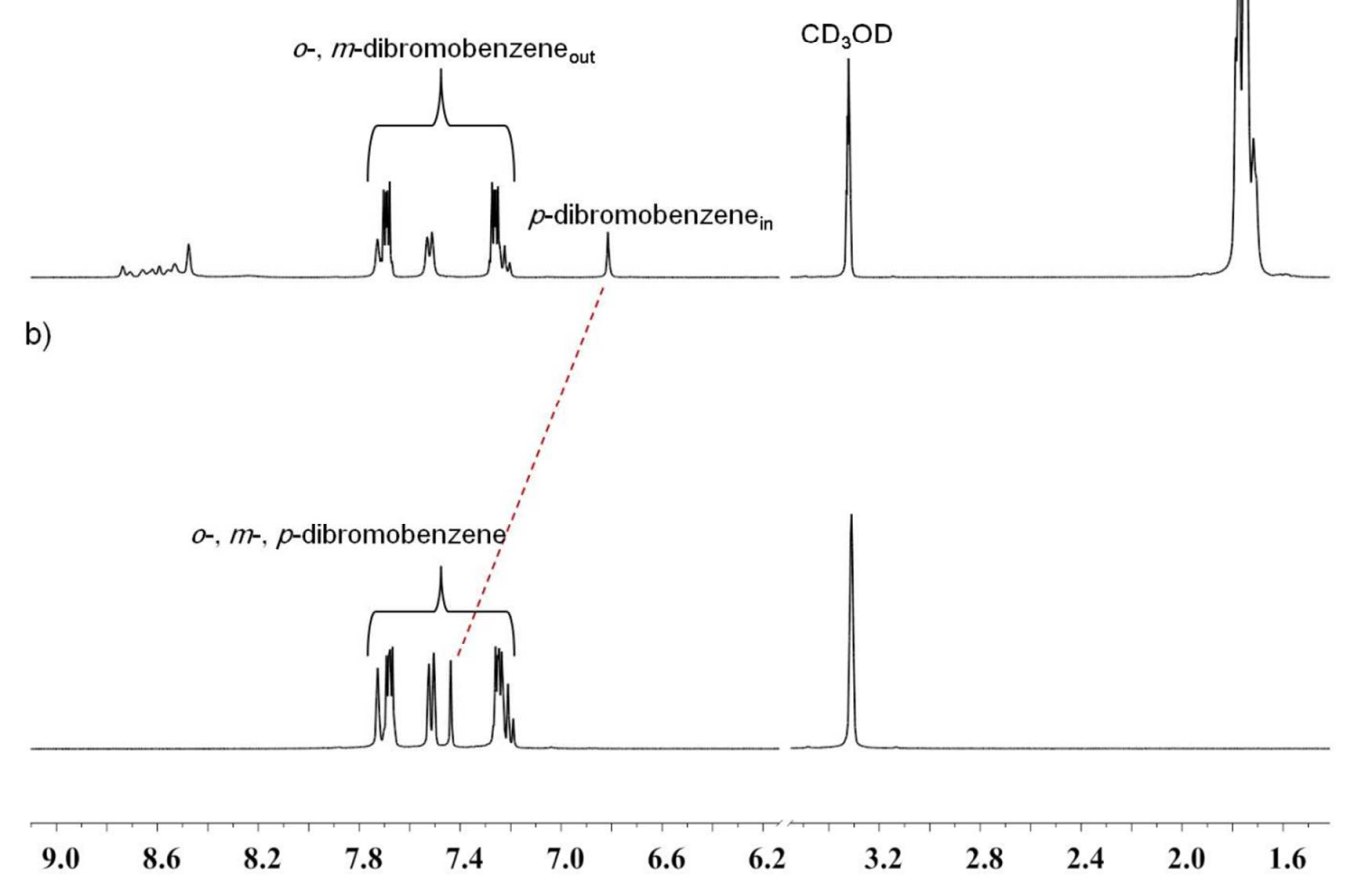

Figure S26. ${ }^{1} \mathrm{H}$ NMR $\left(\mathrm{CD}_{3} \mathrm{OD}, 400 \mathrm{MHz}, 300 \mathrm{~K}, \mathrm{ppm}\right)$ for $(\mathrm{a})$ complex $4(\mathrm{C}=6.4 \mathrm{mM})$ in the presence of $p$-dibromobenzene, $m$-dibromobenzene, $o$-dibromobenzene (molar ratio=1 : $1: 4: 4$ ); (b) o-, $m$-, $p$-dibromobenzene (molar ratio $=4: 4: 1$ ) in $\mathrm{CD}_{3} \mathrm{OD}$. 
a)

b)

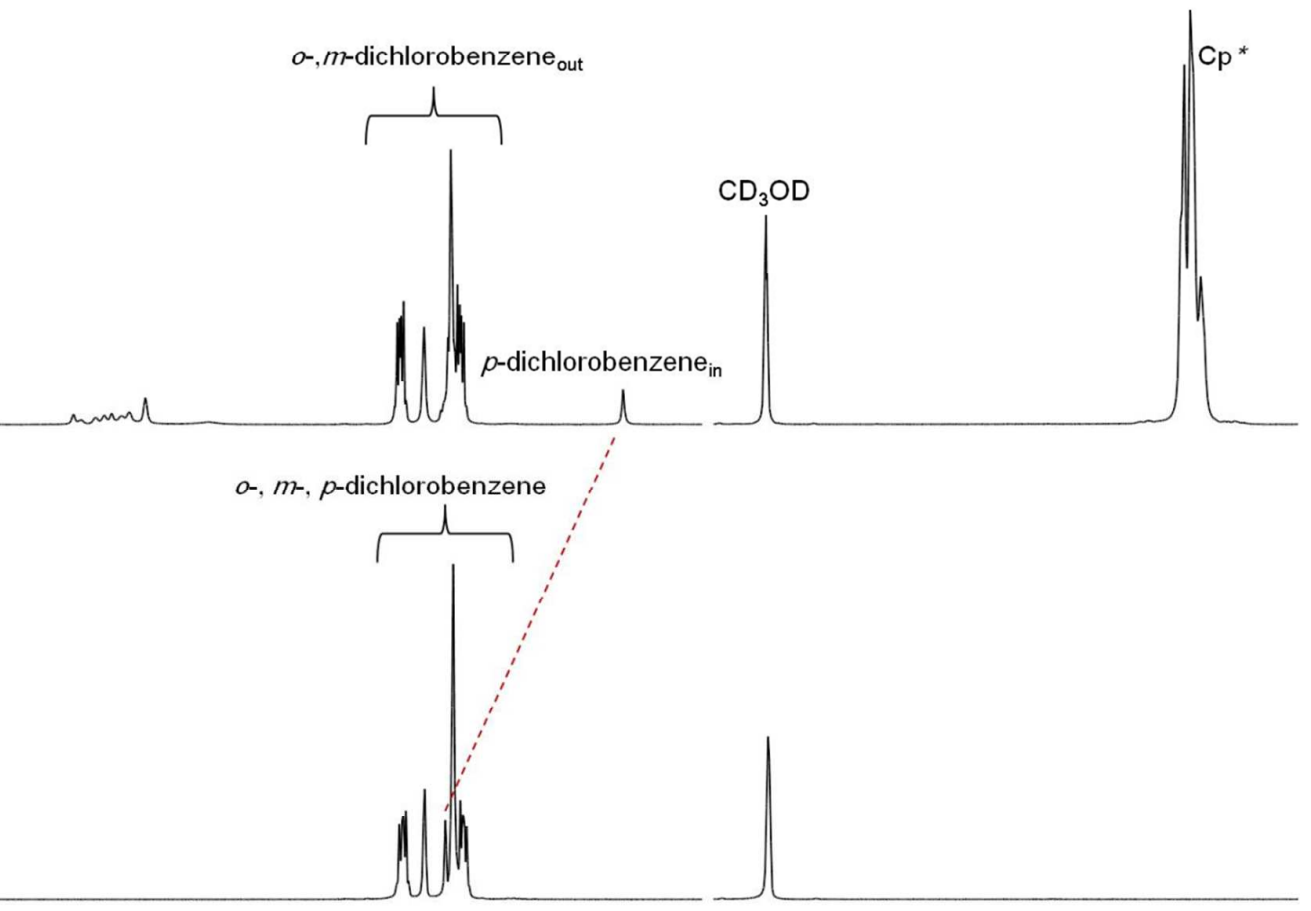

$$
9.0
$$
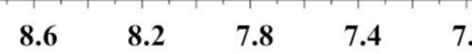

6.6

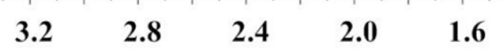

Figure S27. ${ }^{1} \mathrm{H}$ NMR $\left(\mathrm{CD}_{3} \mathrm{OD}, 400 \mathrm{MHz}, 300 \mathrm{~K}, \mathrm{ppm}\right)$ of (a) complex $4(\mathrm{C}=6.4 \mathrm{mM})$ in the presence of $p$-dichlorobenzene, $m$-dichlorobenzene, $o$-dichlorobenzene (molar ratio $=1$ : $1: 4: 4$ ); (b) o-, $m$-, p-dichlorobenzene (molar ratio=4 : $4: 1$ ) in $\mathrm{CD}_{3} \mathrm{OD}$. 
a)
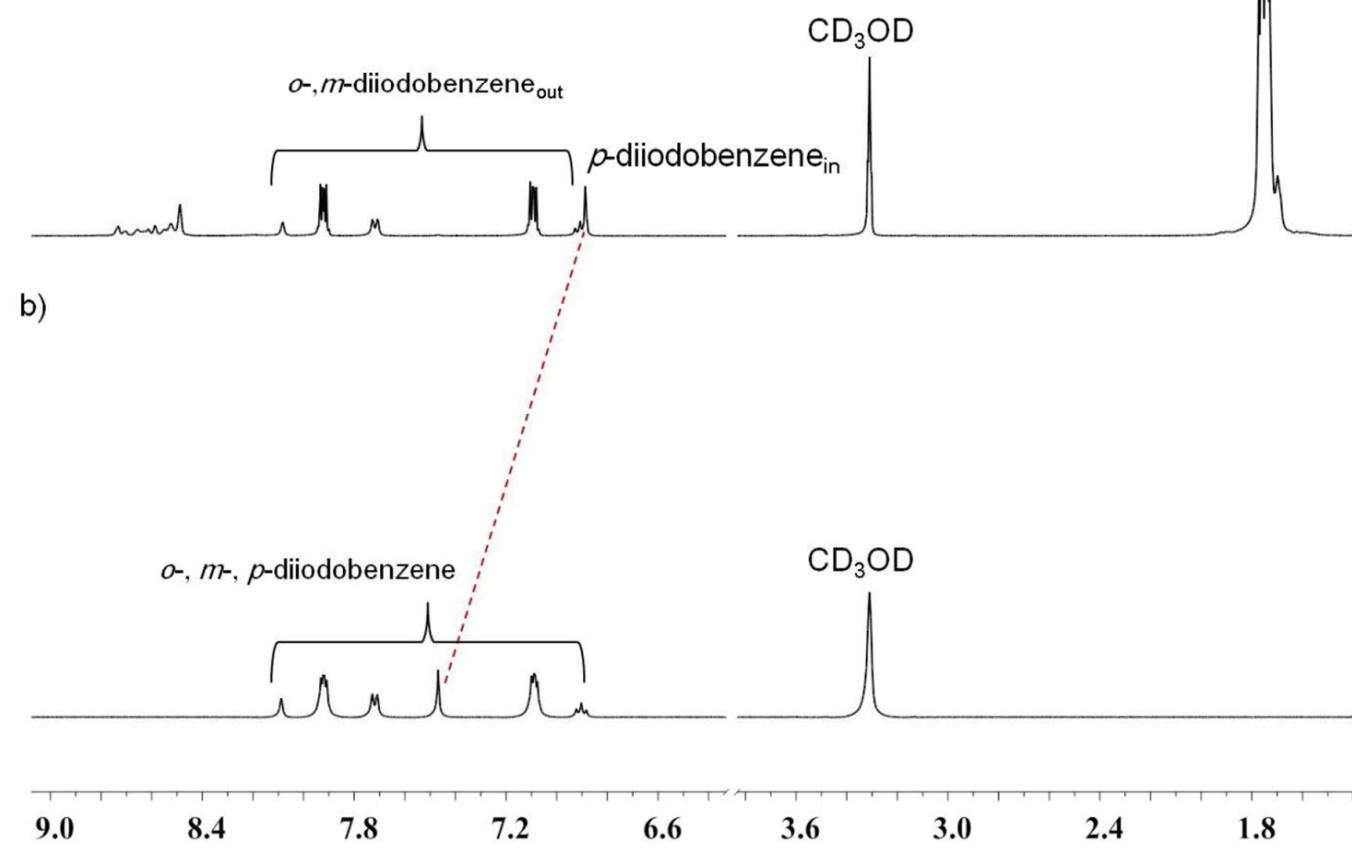

Figure S28. ${ }^{1} \mathrm{H}$ NMR $\left(\mathrm{CD}_{3} \mathrm{OD}, 400 \mathrm{MHz}, 300 \mathrm{~K}, \mathrm{ppm}\right)$ of (a) complex $4(\mathrm{C}=6.4 \mathrm{mM})$ in the presence of $p$-diiodobenzene, $m$-diiodobenzene, o-diiodobenzene (molar ratio $=1: 1: 4$ : 4); (b) o-, $m$-, $p$-diiodobenzene (molar ratio=4 : $4: 1$ ) in $\mathrm{CD}_{3} \mathrm{OD}$. 


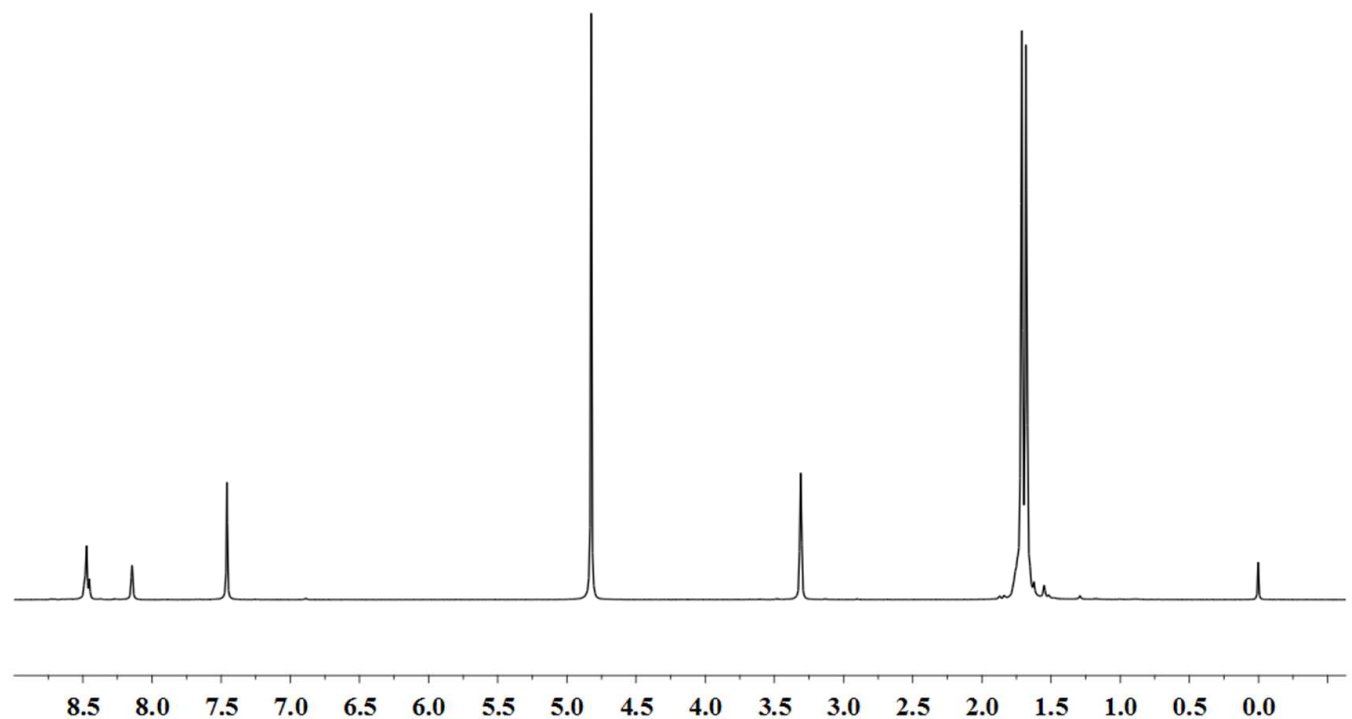

Figure S29. ${ }^{1} \mathrm{H}$ NMR $\left(\mathrm{CD}_{3} \mathrm{OD}, 400 \mathrm{MHz}, 300 \mathrm{~K}, \mathrm{ppm}\right)$ for metallarectangle 3 in the presence of excess $p$-diiodobenzene. 


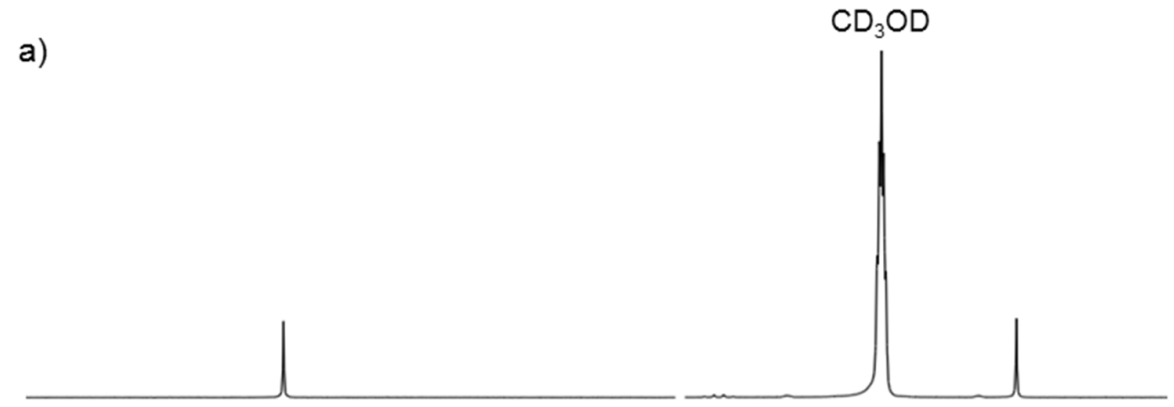

b)

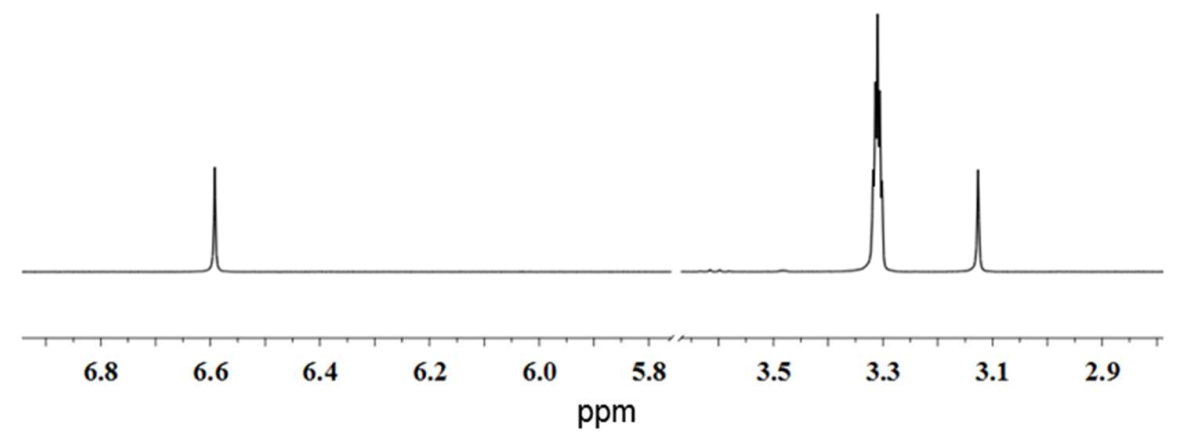

Figure S30. ${ }^{1} \mathrm{H}$ NMR $\left(\mathrm{CD}_{3} \mathrm{OD}, 400 \mathrm{MHz}, 300 \mathrm{~K}\right.$, ppm) for (a) $\mathrm{pCp}$ and (b) the mixture of pCp and AgOTf. 


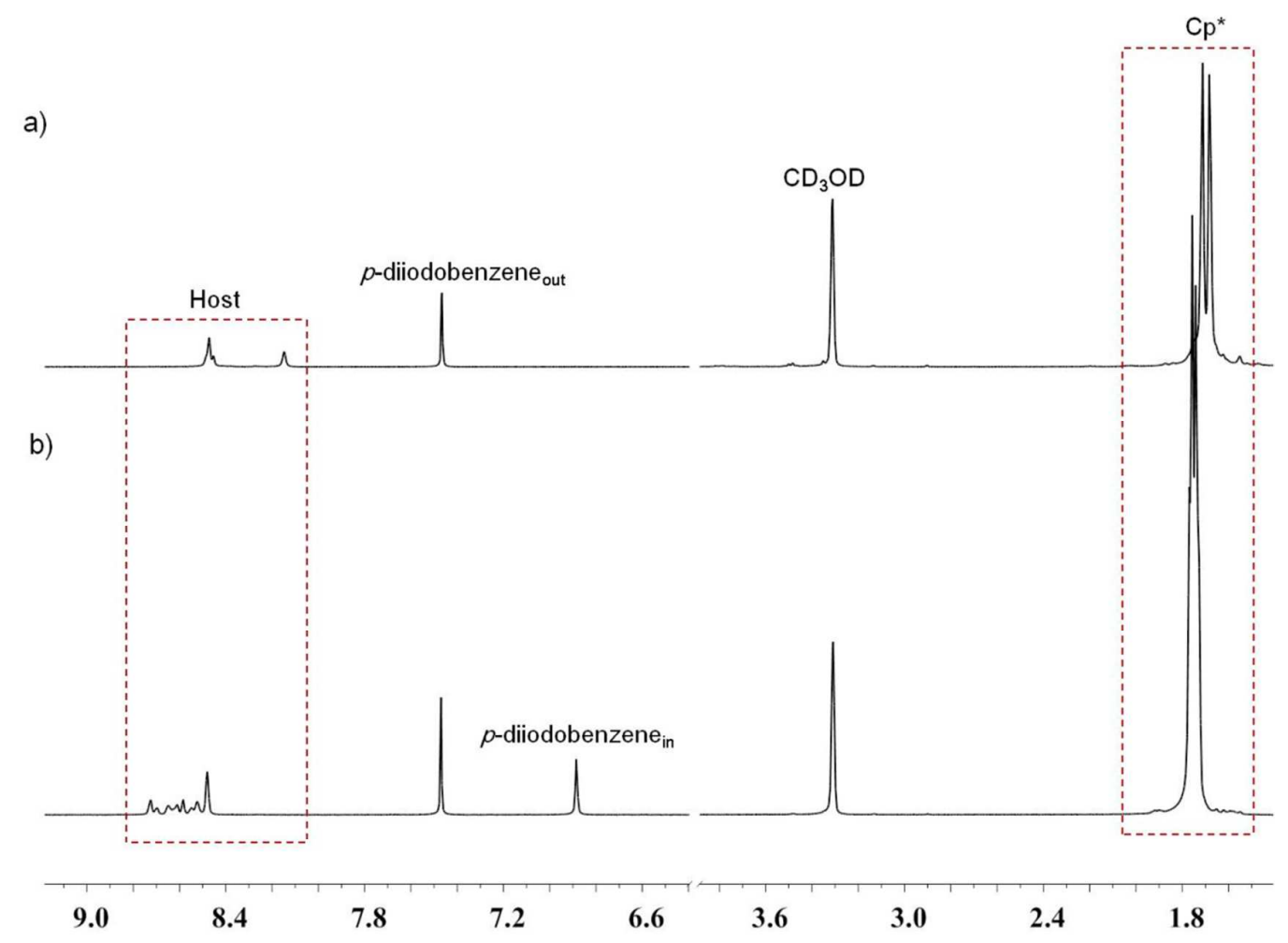

Figure S31. ${ }^{1} \mathrm{H}$ NMR $\left(\mathrm{CD}_{3} \mathrm{OD}, 400 \mathrm{MHz}, 300 \mathrm{~K}\right.$, ppm) for (a) Exposure of the solution of complex $4(C=4.5 \mathrm{mM})$ in the presence of 2.2 equiv. of $p$-diiodobenzene to sunlight for 3 $\mathrm{h}$; (b) complex $4(C=4.5 \mathrm{mM})$ in the presence of 2.2 equiv. of $p$-diiodobenzene. 


\section{X-ray diffraction studies details.}

Data of complex 4 were collected in a Bruker APEX DUO X-ray diffractiometer. In complex 4 there are disordered solvent which cannot be refined properly. Therefore, new data sets corresponding to omission of the disordered solvents were generated with the SQUEEZE algorithm and the structures were refined to convergence. One methanol molecule was disordered and it was refined to two idealized positions (72:28). Atoms O9-11, O15, O18-20, F4-6, F9 and C62 (all of them are atoms of triflate anions) were refined isotropically because of non-positive definition and other non-hydrogen atoms were refined anisotropically. Hydrogen atoms were placed in the geometrically calculated positions with fixed isotropic thermal parameters. However, hydrogen atoms of the solvent water and methanol molecules could not be found.

Data of complex 4' were collected in a Bruker APEX DUO X-ray diffractiometer. In complex 4', there are disordered solvents in the crystal structures which cannot be refined or restrained properly so that the SQUEEZE algorithm was used to omit them. Two water molecules do not occupy their position completely and the occupancy is $50 \%$. The diethyl ether molecule in the cage was disordered and was refined in two idealized positions (40:60). Three methanol molecules were disordered in the crystal structure and they were refined to two idealized positions (80:20, 52:48 and 61:39). Two of eight pentamethylcyclopentadienyl ligands in the cation were also disordered. They were refined to two idealized positions (53:47). One of three triflate anions was disordered and was restrained to two idealized positions (72:28). Atoms 018-20, O9-11, O9'-11', F10-12, C59, C64, C67, C68, C67', C68', O24 and O27' were refined isotropically because of non-positive definition and other non-hydrogen atoms were refined anisotropically. Hydrogen atoms which could be found were placed in the geometrically calculated positions with fixed isotropic thermal parameters. However, hydrogen atoms of all water and some methanol molecules could not be found.

Crystallographic data for complexes for $p$-xylene $\subset 4, p$-dibromobenzene $\subset 4, p C p \subset 4$ 
were collected at $150 \mathrm{~K}$ using a Bruker D8 VENTURE micro-focus X-ray sources system $\left(\mathrm{Cu}_{\mathrm{Ka}}, \lambda=1.54178 \AA\right)$.

In asymmetric unit of $p$-xylene $\subset 4$, there were disordered anions and solvents (half of a triflate anion, half of a $p$-xylene, four methanol and two water molecules) which could not be restrained properly. Therefore, SQUEEZE algorithm was used to omit them.

In asymmetric unit of p-dibromobenzenec4, there were disordered anion and solvents (one triflate anion, two methanol and four water molecules) which could not be restrained properly. Therefore, SQUEEZE algorithm was used to omit them. 23 ISOR, 8 DELU and 12 DFIX instructions were used to restrain anions, solvents and $\mathrm{Cp}^{*}$ fragments so that there were 158 restraints in the data. Hydrogen of methanol molecules could not be found and others were put in calculated positions.

In asymmetric unit of $\mathrm{pCp} \subset 4$, there were disordered anions and solvents (four triflate anions, five methanol and twelve water molecules) which could not be restrained properly. Therefore, SQUEEZE algorithm was used to omit them. One of eight pentamethylcyclopentadienyl ( $\mathrm{Cp}^{*}$ for short) ligand was disordered and it was divided into two parts (52:48). 42 ISOR, 5 DELU and 29 DFIX instructions were used to restrain anions, solvents and $\mathrm{Cp}^{*}$ fragments so that there were 286 restraints in the data. Hydrogen of disordered methanol molecule could not be found and others were put in calculated positions. 
Table S1. Crystal data for complexes 3, 4 and 4'.

\begin{tabular}{|c|c|c|c|}
\hline Complex & 3 & 4 & $4^{\prime}$ \\
\hline empirical formula & $\mathrm{C}_{65} \mathrm{H}_{74} \mathrm{Cl}_{8} \mathrm{~F}_{6} \mathrm{~N}_{4} \mathrm{O}_{15} \mathrm{Rh}_{4} \mathrm{~S}_{2}$ & $\mathrm{C}_{130} \mathrm{H}_{152} \mathrm{Ag}_{2} \mathrm{Cl}_{8} \mathrm{~F}_{18} \mathrm{~N}_{8} \mathrm{O}_{40} \mathrm{Rh}_{8} \mathrm{~S}_{6}$ & $\mathrm{C}_{138} \mathrm{H}_{182} \mathrm{Ag}_{2} \mathrm{Cl}_{8} \mathrm{~F}_{18} \mathrm{~N}_{8} \mathrm{O}_{47} \mathrm{Rh}_{8} \mathrm{~S}_{6}$ \\
\hline$T[\mathrm{~K}]$ & $173(2)$ & $173(2)$ & $173(2)$ \\
\hline$M_{\mathrm{r}}$ & 2024.64 & 4591.4 & 4561.90 \\
\hline crystal size $\left[\mathrm{mm}^{3}\right]$ & $0.30 \times 0.14 \times 0.09$ & $0.21 \times 0.31 \times 0.17$ & $0.34 \times 0.31 \times 0.17$ \\
\hline Crystal System & Monoclinic & Triclinic & Triclinic \\
\hline Space group & $P 2_{1} / m$ & $P-1$ & $P-1$ \\
\hline a $[\AA]$ & $8.661(2)$ & $14.7340(9)$ & $14.780(2)$ \\
\hline $\mathrm{b}[\AA]$ & $26.064(7)$ & $19.3519(11)$ & $19.428(3)$ \\
\hline$c[\AA]$ & $17.124(4)$ & $19.3924(11)$ & $19.428(3)$ \\
\hline$\alpha\left[^{\circ}\right]$ & 90 & $60.7300(10)$ & $60.753(2)$ \\
\hline$\beta\left[^{\circ}\right]$ & $95.174(4)$ & $72.1580(10)$ & $72.064(2)$ \\
\hline $\mathrm{y}\left[{ }^{\circ}\right]$ & 90 & $81.1670(10)$ & $81.373(2)$ \\
\hline$V\left[\AA^{3}\right]$ & $3849.7(16)$ & $4591.4(5)$ & $4630.9(11)$ \\
\hline$Z$ & 2 & 1 & 1 \\
\hline$\rho_{\text {calco }}\left[\mathrm{g} \mathrm{cm}^{-3}\right]$ & 1.747 & 1.564 & 1.636 \\
\hline$\mu\left(\mathrm{Mo}_{\kappa \alpha}\right)\left[\mathrm{mm}^{-1}\right]$ & 1.253 & 1.177 & 1.174 \\
\hline$F(000)$ & 2028 & 2156 & 2290 \\
\hline$\theta$ range $\left[^{\circ}\right]$ & $1.19-25.01$ & $1.27-26.01$ & $1.20-25.01$ \\
\hline \multirow[t]{3}{*}{ limiting indices } & $-10 \leq h \leq 10$ & $-16 \leq h \leq 18$ & $-17 \leq h \leq 17$ \\
\hline & $-31 \leq k \leq 30$ & $-18 \leq k \leq 23$ & $-23 \leq k \leq 23$ \\
\hline & $-19 \leq I \leq 20$ & $-23 \leq / \leq 23$ & $-23 \leq I \leq 21$ \\
\hline
\end{tabular}

S37 


\begin{tabular}{|c|c|c|c|c|}
\hline & collected reflns & 22477 & 30257 & 26021 \\
\hline & unique reflns & 6873 & 17756 & 15681 \\
\hline Complex & absorption correction & $\begin{array}{c}\text { semiempirical } \\
p \text {-xylene } \subset 4\end{array}$ & $\begin{array}{c}\text { semiempirical } \\
p \text {-dibromobenzene } \subset \mathbf{4}\end{array}$ & $\begin{array}{ll}\text { semiempirical } & \mathrm{pCp} \subset \mathbf{4}\end{array}$ \\
\hline empirical & $\begin{array}{l}\text { max. I ImIn. Iransmissions } \\
\text { I formula }\end{array} \mathrm{C}_{154} \mathrm{H}_{208}$ & ${ }_{8} \mathrm{Agg}_{2} \mathrm{Cl}_{8} \mathrm{~F}_{18} \mathrm{~N}_{8} \mathrm{O}_{50} \mathrm{Rh}_{8} \mathrm{~S}_{6}$ & $0.922270 .79022 \mathrm{C}_{140} \mathrm{H}_{184} \mathrm{Ag}_{2} \mathrm{Br}_{2} \mathrm{Cl}_{8} \mathrm{~F}_{18} \mathrm{~N}_{8} \mathrm{O}_{50} \mathrm{Rh}_{8} \mathrm{~S}_{6}$ & ${ }_{6}^{0.0254} \mathrm{C}_{140.50} \mathrm{H}_{190} \mathrm{Ag}_{2} \mathrm{Cl}_{8} \mathrm{~F}_{18} \mathrm{~N}_{8} \mathrm{O}_{52.50} \mathrm{Rh}_{8} \mathrm{~S}_{6}$ \\
\hline$\pi \mathrm{K}]$ & $\begin{array}{r}\text { data / restraints / parameters } \\
150(2)\end{array}$ & $6873 / 32$ / 497 & $\begin{array}{l}17756 / 61 / 1014 \\
150(2)\end{array}$ & $\begin{array}{l}15681 / 97 / 1155 \\
150(2)\end{array}$ \\
\hline$M_{\mathrm{r}}$ & goodness of fit & $5^{1.154}$ & $\begin{array}{l}1.072 \\
4795.74\end{array}$ & $\begin{array}{l}1.565 \\
4687.97\end{array}$ \\
\hline & $R_{1} / w R_{2}[1>2 \sigma(I)]^{[a]}$ & $0.1200 / 0.2976$ & $0.0658 / 0.1923$ & $0.0971 / 0.3067$ \\
\hline & $R_{1} / w R_{2}(\text { all data })^{a}$ & $0.1393 / 0.3074$ & $0.1029 / 0.2150$ & $0.1123 / 0.3461$ \\
\hline
\end{tabular}

Table S2. Crystal data for inclusion complexes. 


\begin{tabular}{|c|c|c|c|}
\hline crystal size $\left[\mathrm{mm}^{3}\right]$ & $0.57 \times 0.18 \times 0.14$ & $0.25 \times 0.22 \times 0.18$ & $0.32 \times 0.31 \times 0.16$ \\
\hline Crystal System & Monoclinic & Orthorhombic & Triclinic \\
\hline Space group & C1 2/c 1 & $P$ b c m & $P-1$ \\
\hline $\mathrm{a}[\AA]$ & $23.9798(6)$ & $31.0886(10)$ & $19.9065(15)$ \\
\hline $\mathrm{b}[\AA]$ & $30.8569(8)$ & $16.9869(6)$ & $23.0344(18)$ \\
\hline$c[\AA]$ & $31.5989(9)$ & $36.8332(14)$ & $25.5143(18)$ \\
\hline$\alpha\left[{ }^{\circ}\right]$ & 90 & 90 & $78.930(4)$ \\
\hline$\beta\left[^{\circ}\right]$ & $112.0177(11)$ & 90 & $72.422(4)$ \\
\hline $\mathrm{V}\left[{ }^{\circ}\right]$ & 90 & 90 & $88.438(4)$ \\
\hline$V\left[\AA^{3}\right]$ & 21676.1(10) & $19451.6(12)$ & $10939.5(14)$ \\
\hline Z & 4 & 4 & 2 \\
\hline$\rho_{\text {calco }}\left[\mathrm{g} \mathrm{cm}^{-3}\right]$ & 1.480 & 1.638 & 1.423 \\
\hline$\mu\left(\mathrm{Cu}_{\mathrm{K \alpha}}\right)\left[\mathrm{mm}^{-1}\right]$ & 8.379 & 9.797 & 8.293 \\
\hline$F(000)$ & 9744 & 9592 & 4714 \\
\hline$\theta$ range $\left[{ }^{\circ}\right]$ & $2.455-68.359$ & $2.399-67.993$ & 2.992- 66.999 \\
\hline \multirow[t]{3}{*}{ limiting indices } & $-28 \leq h \leq 28$ & $-37 \leq h \leq 37$ & $-23 \leq h \leq 23$ \\
\hline & $-37 \leq k \leq 37$ & $-20 \leq k \leq 13$ & $-22 \leq k \leq 27$ \\
\hline & $-38 \leq I \leq 20$ & $-44 \leq 1 \leq 42$ & $-30 \leq 1 \leq 28$ \\
\hline collected reflns & 112245 & 66410 & 92066 \\
\hline unique reflns & 19715 & 17877 & 35219 \\
\hline absorption correction & Semiempirical & semiempirical & semiempirical \\
\hline max. / min. transmissions & $0.3201 / 0.1126$ & $0.573 / 0.294$ & $0.2709 / 0.0980$ \\
\hline data / restraints / parameters & 19715 / $191 / 1089$ & 17877 / 158 / 981 & $35219 / 286 / 1627$ \\
\hline goodness of fit & 1.074 & 1.045 & 1.116 \\
\hline
\end{tabular}


$R_{1} / w R_{2}[1>2 \sigma(I)]^{[a]}$

$R_{1} / w R_{2}(\text { all data })^{\mathrm{a}}$
$0.0590 / 0.1619$

$0.0658 / 0.1667$
$0.1113 / 0.2963$

$0.1359 / 0.3172$
$0.1421 / 0.3541$

$0.1663 / 0.3732$ 